\title{
Identification of major moisture sources across the Mediterranean Basin
}

\author{
Fulden Batibeniz ${ }^{1,2}$ (1) $\cdot$ Moetasim Ashfaq ${ }^{1} \cdot$ Barış Önol $^{2} \cdot$ Ufuk Utku Turuncoglu $^{4} \cdot$ Shahid Mehmood ${ }^{1,3}$. \\ Katherine J. Evans ${ }^{1}$
}

Received: 15 September 2019 / Accepted: 28 March 2020 / Published online: 9 April 2020

(c) The Author(s) 2020

\begin{abstract}
We employ a Lagrangian based moisture back trajectory method on an ensemble of four reanalysis datasets to provide a comprehensive understanding of moisture sources over the Mediterranean land region $\left(30^{\circ} \mathrm{N}-49.5^{\circ} \mathrm{N}\right.$ and $\left.9.75^{\circ} \mathrm{W}-61.5^{\circ} \mathrm{E}\right)$ at seasonal timescales for 1980-2013 period. Using a source region between $10^{\circ} \mathrm{S}-71.35^{\circ} \mathrm{N}$ along the latitude and $80^{\circ} \mathrm{W}-84.88^{\circ} \mathrm{E}$ along the longitude that is subdivided into ten complimentary sub-regions, our analyses is able to backtrack up to $>90 \%$ of seasonal precipitation at each grid point within the target region. Our results indicate a significant role of moisture advected from the North Atlantic and Mediterranean Sea, and locally recycled moisture over the target region in shaping the spatial organization of seasonal precipitation. However, a clear east-west contrast is witnessed in determining the relative importance of each of these major moisture sources where the North Atlantic dictates the moisture supply over the western Mediterranean while moisture from Mediterranean Sea and local recycling play a key role over the eastern Mediterranean. Our analyses also demonstrate a major footprint of the North Atlantic Oscillation (NAO) on precipitation variability over the Mediterranean land as dynamic and thermodynamic anomalies during the negative phase of NAO match with those during wet years and vice versa. The findings reported here are generally consistent across the four reanalysis datasets. Overall, this study establishes the relative roles of adjacent and far-off oceanic and terrestrial evaporative sources over the Mediterranean land and should help in understanding the drivers of precipitation variability and change at varying timescales.
\end{abstract}

\section{Introduction}

The Mediterranean region is known for relatively hot and dry summers and mild and moist winters. The movement of highpressure cells, including the Azores High, South Atlantic High, North Pacific High, South Pacific High, and the Indian Ocean High, influence seasonal characteristics of climate within the Mediterranean region (Nieto et al. 2010; Schicker

Fulden Batibeniz

batibenizf@itu.edu.tr

1 Computational Sciences and Engineering Division, Oak Ridge National Laboratory, Oak Ridge, TN, USA

2 Aeronautics and Astronautics Faculty, Meteorological Engineering, Istanbul Technical University, Istanbul, Turkey

3 Research Center for Environmental Changes (RCEC), Taiwan International Graduate Program (TIGP) Academia Sinica, Taipei, Taiwan

4 National Center for Atmospheric Research, Boulder, CO, USA et al. 2010; Xoplaki et al. 2012). In winter, high-pressure cells move equatorward, allowing for the intrusion of storms associated with the polar jet stream, which result in heavy precipitation events during the season. In summer, highpressure cells move poleward, allowing for the intrusion of dry continental air, which enhances aridity by reducing precipitation events. Within the Mediterranean climate region, the Mediterranean Basin (hereafter MB) encompasses the Mediterranean Sea and includes both European and Middle Eastern countries. The MB is considered a hotspot for climate change because of its strong precipitation seasonality and high population density. Moreover, due to the combination of diverse regions with very complex topography (i.e. Alps, Anatolian Peninsula), different land-use characteristics (i.e. rocky shores, impenetrable scrub, semi-arid steppes, coastal wetlands) and large waterbodies (i.e. Mediterranean and the Black Sea) (Turuncoglu and Sannino 2017), the MB exhibits strong spatial heterogeneity in precipitation and temperature distribution. Therefore, the MB is critical for the study of moisture sources that shape complex precipitation dynamics. 
Earlier investigations have shown that the MB contributes a significant amount of moisture to the entire Northern Hemisphere, particularly in terrestrial regions immediately adjacent to it (Gómez-Hernández et al. 2013; Mariotti et al. 2002; Nieto et al. 2010; Schicker et al. 2010).

The Mediterranean is at a crossroad of airstreams where air enters mainly from the northwest and continues in two separate streams, one going southwest over North Africa into the trade wind zone and the other to the northeast through Central Asia (Schicker et al. 2010). This suggests an abundance of moisture may be sourced through the Atlantic and areas westward. Recent studies also indicate a role of atmospheric rivers and tropical plumes in moisture supply through mid-latitude and tropical interactions (Bozkurt et al. 2019; Dezfuli 2019). Future increases in greenhouse gas forcing will likely increase land, ocean, and atmosphere temperatures, which may lead to higher moisture content in the air and stronger evaporation rates over terrestrial and oceanic regions (Christensen et al. 2007; Önol et al. 2014). Such changes will influence moisture transport to and from the MB, likely impacting the regional precipitation distribution through the modification of the hydrological cycle. Therefore, it is important to establish a clear understanding of moisture sources over the MB, their inter-annual and seasonal variations under various largescale forcing, and subsequent factors that influence mean and extreme seasonal precipitation distributions.

In a regional hydrological cycle, the precipitation that occurs over a specific region comes from one of three possible sources at a given time (Brubaker et al. 1993; Burde and Zangvil 2001; Ciric et al. 2018; Dominguez et al. 2006; Dominguez and Kumar 2008; Drumond et al. 2011; Eltahir and Bras 1996; Gómez-Hernández et al. 2013; Schicker et al. 2010; Trenberth 1999): moisture already present in the atmosphere, moisture advected by atmospheric transport into the region, and moisture in the atmosphere due to local evapotranspiration or moisture recycling. Among these three factors, advection and local moisture recycling are the two main moisture sources shaping the precipitation dynamics over a specific region. Many methodologies such as analytical models, box models, isotopes, and numerical water vapor tracers have been used to identify these geographical moisture sources and sinks over the regions of interest (Gimeno et al. 2012). However, Lagrangian techniques are the most commonly used method due to their ability to determine long-term moisture source and sink relationships (Gimeno et al. 2012). Over the MB, previous studies have investigated moisture sources through the use of the numerical 3D Lagrangian Flexible Particle Dispersion Model (FLEXPART) (Stohl and James 2004, 2005). For instance, Nieto et al. (2010), Drumond et al. (2011) and Schicker et al. (2010) investigated moisture sources and sinks for 2000-2005. These studies established that the Mediterranean Sea is one of the main moisture sources for the MB. Among these three studies, only Drumond et al. (2011) focused on the seasonality of moisture sources and found that the contribution from the Atlantic progressively decreased going from winter to summer as the Mediterranean Sea becomes the main moisture source for the warm season. More recently, Hernández et al. (2013) extended earlier work by analyzing moisture sources over longer time periods for eight target regions (Iberian Peninsula, Italy, France, the Balkan Peninsula, the Eastern Mediterranean, and three regions of North Africa: West, Central, and East) and identified the western Mediterranean Sea as the main source region for almost all target regions during the October to March wet season. Moreover, Ciric et al. (2018) found that while the Mediterranean Sea was an important source during extreme precipitation years for some European regions, it was not an important contributor for seasonal mean precipitation.

Dissimilarities in earlier studies are due in part from differences in time periods, datasets, analyses, and methodologies used for the identification of moisture sources. Therefore, despite this large body of work, a comprehensive and robust understanding of moisture sources over the MB at climatological time scales is currently lacking. In order to improve on these limitations, in this study, we make use of a longer timescale and a larger spatial domain for the identification of moisture sources, in addition to the use of four different reanalysis datasets. Additionally, we employ a Lagrangian moisture-tracking model that has not been previously used over this region. This model, formally known as a dynamic recycling model (DRM), was originally developed by Dominguez et al. (2006). Unlike the FLEXPART model, this method does not have immanent dependence on physical parametrizations (Dominguez et al. 2006; Gimeno et al. 2012; Stohl and James 2004). Together, these methodological choices should allow for a more rigorous investigation of moisture sources over the MB at climatological timescales and may help to explain the thermodynamic drivers of observed precipitation variability. Moreover, the use of a different moisture tracking method, multiple datasets and a long timescale should help in the identification of robust features of moisture sources over the MB, particularly those that are supported by earlier studies based on other methods or in the understanding of the causes of disagreements among previous studies. The details of data and methodology are described in Sect. 2. Major moisture sources, their interannual variability, long-term trends and influence of remote forcing is detailed in Sect. 3. Discussion and summary are given in Sects. 4 and 5, respectively.

\section{Data and methods}

We used a Lagrangian moisture tracking algorithm, described in Mei et al. (2015), to perform moisture source analysis over the MB. This method has been used extensively over many regions including South Asia (Ashfaq 
et al. 2017; Mei et al. 2015; Pathak et al. 2017; Roxy et al. 2017; Sahana et al. 2019), North America and South America (Dominguez et al. 2006; Dominguez and Kumar 2008; Martinez and Dominguez 2014). We refer the reader to Mei et al. (2015) for a detailed description of methodology. In brief, this methodology makes use of the water vapor mass conservation equation with the assumption that the atmospheric column is well mixed, meaning that at each grid cell the ratio of local recycled precipitation to advected precipitation is equal to the ratio of evaporated to advected water vapor in the atmospheric column. At each time step, the advected moisture is backtracked both in space and time until the back trajectory reaches the boundary of the predefined source region. Using the well-mixed assumption of the vertical column, the moisture back tracking follows a 2D path as all the atmospheric fields are vertically integrated. The use of a 2D approach may cause erroneous advection in regions with a strong vertical shear of winds, such as in the tropics, but it has been known to have little impact in the extratropical climates, such as the Mediterranean. Another drawback of this methodology is that oftentimes water vapor mass conservation may not be valid in the case of reanalysis datasets due to their use of data assimilation. While a correction factor can be applied to overcome this issue, there is no systematic way to account for this correction term due to the lack of long-term in-situ observations or remotely sensed records for most of the variables involved in the calculations. In any case, it has been shown that most of the variables used in the computation of back trajectories of moisture are not significantly impacted by this correction term (Dominguez et al. 2006).

For this study, we define Mediterranean Land (ML) as our target region. The ML spans $30^{\circ} \mathrm{N}-49.5^{\circ} \mathrm{N}$ along the latitude and $9.75^{\circ} \mathrm{W}-61.5^{\circ} \mathrm{E}$ along the longitude. In order to understand region specific moisture contributions over the target region, we further define ten complementary regions (five oceanic and five terrestrial) as moisture sources: (1) Mediterranean Sea (MS), (2) North American Continent (NAC), (3) Black Sea and Caspian Sea (BCS), (4) North Atlantic (NA), (5) Mediterranean Land (ML; Local recycling), (6) Northern Africa (NAF), (7) Northern Europe (NE), (8) Arabian Sea (AS), (9) South Asia (SA), (10) MidAtlantic (MA) (Fig. 1). Overall, the precipitation at each grid point over the ML region is backtracked over a source region between $10^{\circ} \mathrm{S}-71.35^{\circ} \mathrm{N}$ along the latitude and $80^{\circ}$ $\mathrm{W}-84.88^{\circ} \mathrm{E}$ along the longitude, which is subdivided into ten regions as defined above. The boundaries defining the overall moisture source domain and each of the sub-regions are shown in Fig. 1. The sub-division of the source region is based on the relative homogeneity of the climate characteristics within each sub region. Additionally, we keep land and sea regions separate in the sub-division to keep a distinction between terrestrial and oceanic moisture sources. For each moisture back trajectory, we utilize 20 days as an integration time for moisture source identification, which is sufficiently long to account for the residence time of water vapor in the atmosphere (Nieto and Gimeno 2019).

The algorithm requires daily evaporation, precipitation, total column of water vapor, and 6-h three-dimensional horizontal winds and specific humidity for moisture tracking. We make use of four reanalysis products for these analyses, including European Center for Medium-Range Weather Forecast (ECMWF), Reanalysis (ERA-Interim; Dee et al. 2011), National Aeronautics and Space AdministrationGlobal Modeling and Assimilation Office (NOAA), Modern Era Retrospective-Analysis for Research and Applications (MERRA2; Rienecker et al. 2011), National Center for Atmospheric Research Climate (NCAR), Climate Forecast System Reanalysis (CFSR; Saha et al. 2010, 2014) and Kobayashi, Shinya \& National Center for Atmospheric
Fig. 1 Domain used for moisture source analyses. Colors represent different evaporative sub-regions

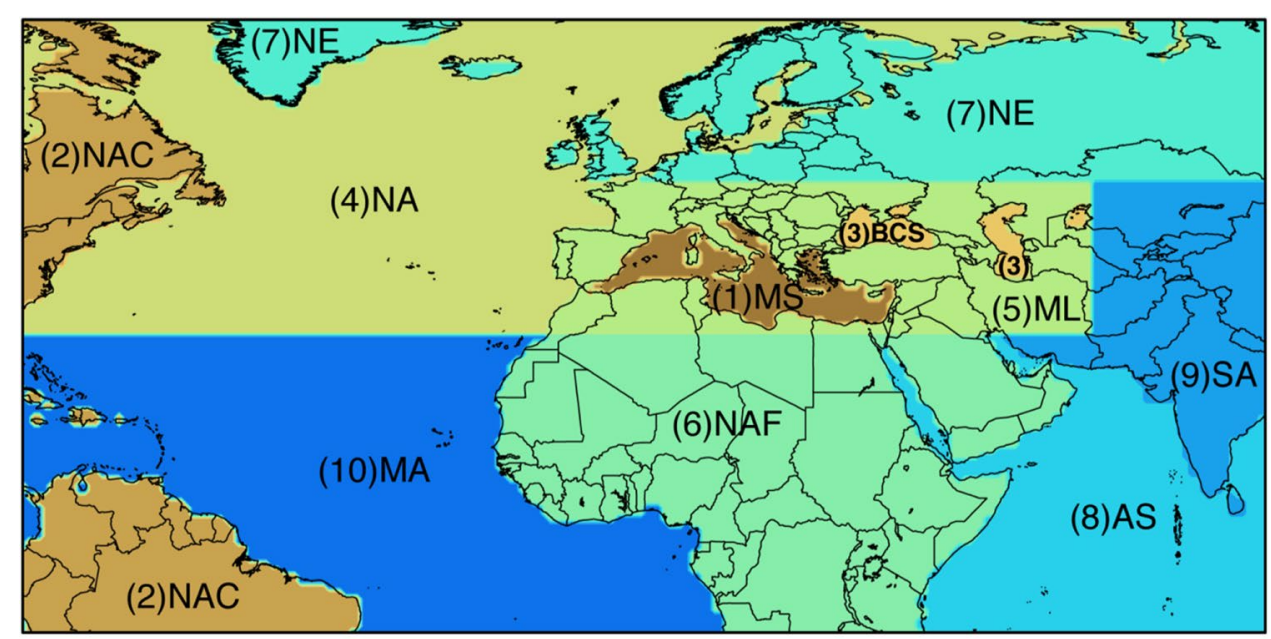

$2 \quad 3$ \begin{tabular}{l|l}
\hline & 4
\end{tabular}
5
6
7
8
9

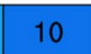


Research-Japanese 25-year Reanalysis (JRA25; Ebita et al. 2011) (Table 1). We linearly interpolate all of the reanalysis datasets to $0.75^{\circ} \times 0.75^{\circ}$ ERA-Interim grid for overlapping the historical period between 1980 and 2013 before the calculation of moisture back trajectories. Unless otherwise mentioned, all results are presented as an ensemble mean of four datasets.

For the consistency of moisture back trajectories, such analysis makes use of precipitation and other variables from the same data source. Given that no gridded long-term observational records are available for all of the variables needed for the calculation of moisture back trajectories, the precipitation in our analyses also comes from the respective reanalysis. We understand that this methodological constraint has the potential to induce errors in the relative contribution of moisture from different evaporative sources due to errors in precipitation distribution. For that reason, we provide a seasonal comparison of reanalysis based precipitation with the Climate Research Unit (CRU; New et al. 2002) and Climate Hazards Group InfraRed Precipitation with Station data (CHIRPS; Funk et al. 2015) observations over land and Multi-Source Weighted Ensemble Precipitation (MSWEP V2; Beck et al. 2019) observations over the sea/ocean to highlight differences in seasonal precipitation distribution across the reanalysis datasets (Fig. 2). The two observations are quite similar in their precipitation distribution in space

Table 1 Details of reanalysis products and observations

\begin{tabular}{lll}
\hline Datasets & Long name & Resolution and time coverage \\
\hline ERA-Interim & ECMWF re-analysis & $0.75^{\circ} \times 0.75^{\circ}$ latitude/longitude resolution (1 January 1979-31 August 2019) \\
MERRA2 & $\begin{array}{l}\text { Modern-era retrospective analysis for } \\
\text { research and applications }\end{array}$ & $0.5^{\circ}$ latitude $\times 0.625^{\circ}$ longitude (1980-2019) \\
& Climate forecast system reanalysis & $0.5^{\circ} \times 0.5^{\circ}$ latitude/longitude resolution (1980-2010) \\
CFSR & & $1^{\circ} \times 1^{\circ}$ latitude/longitude resolution (2011-2013) \\
& Japanese re-analysis & $1.25^{\circ} \times 1.25^{\circ}$ Gaussian grid spacing and 12 atmospheric levels for 3-D \\
JRA25 & & $1.125 \times \sim 1.121$ Gaussian grid (1957 December-2019 July) \\
& & $0.5^{\circ} \times 0.5^{\circ}$ latitude/longitude resolution (1901-2013) \\
CRU & Climate research unit & $0.05^{\circ} \times 0.05^{\circ}$ latitude/longitude resolution (1981 January-2019 October) \\
CHIRPS & Climate hazards group infrared precipita- \\
& tion with station data & \\
\hline
\end{tabular}

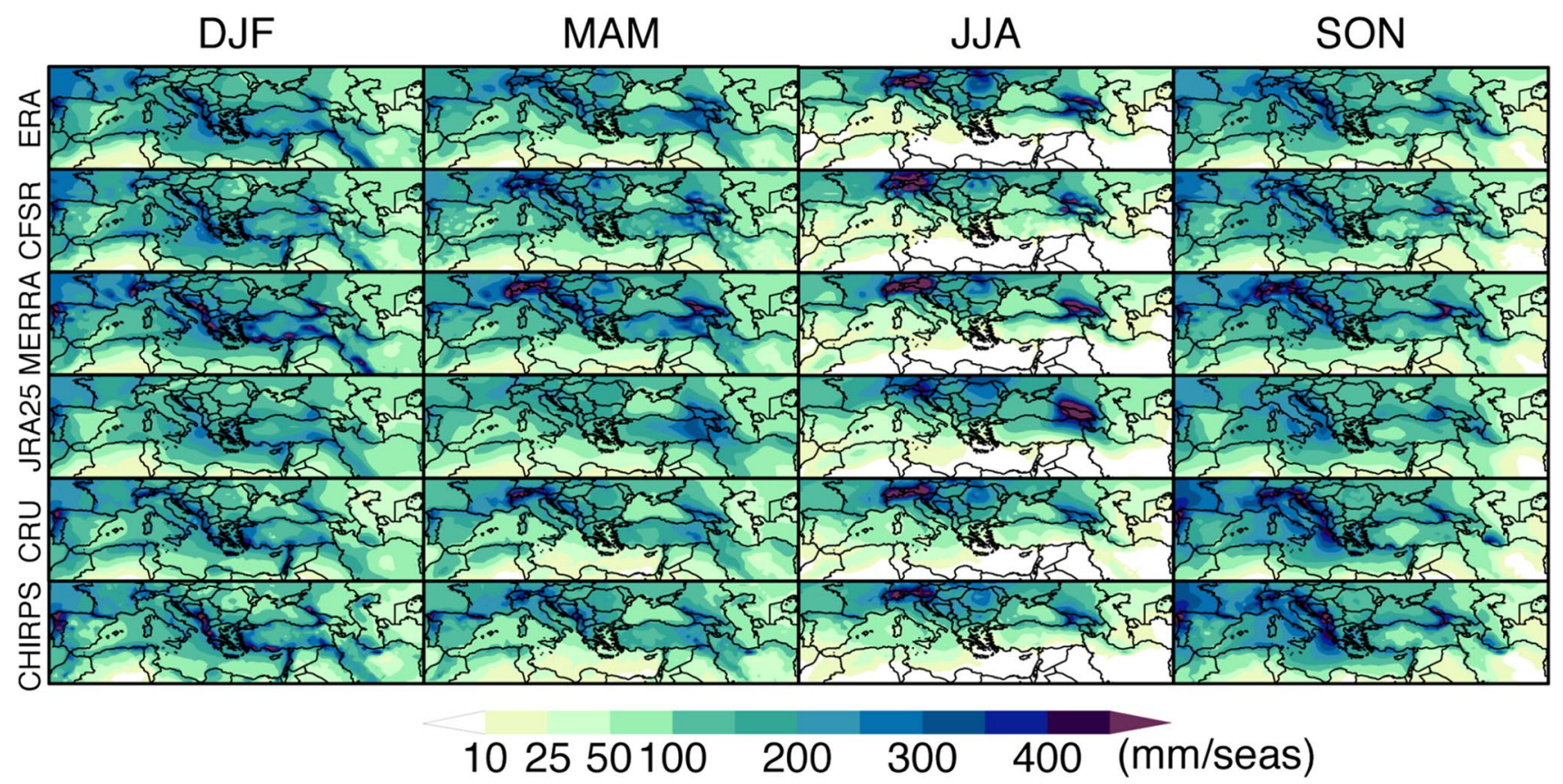

Fig. 2 Seasonal precipitation distribution in the reanalysis (ERA, CFSR, MERRA, JRA25) and the observations (CRU and CHIRPS over land, MSWEP over sea) 
and time. While the spatial and seasonal distribution of precipitation is also quite similar across the four datasets, there are some noticeable differences over the higher elevations where precipitation magnitudes are generally over (under) estimated in MERRA2 (JRA25).

We also investigate the influence of large scale forcing, including the El Niño-Southern Oscillation (ENSO) and North Atlantic Oscillations (NAO), on the precipitation distribution over the study area. For our analyses, we use monthly Hurrell NAO index data from the National Center for Atmospheric Research (data is retrieved from https:// climatedataguide.ucar.edu/climate-data/hurrell-north-atlan tic-oscillation-nao-index-pc-based). This index shows the movement of NAO by tracking movements of the Icelandic Low and the Azores High. Similarly, we use monthly Southern Oscillation Index data from the National Weather Service Climate Prediction Center of National Oceanic and Atmospheric Administration (NOAA) (Data is retrieved from https://www.cpc.ncep.noaa.gov/data/indices/soi). Both monthly indices are averaged to calculate seasonal averages. Subsequently, we use one standard deviation as a threshold to define positive and negative phases of NAO and ENSO. We also define wet and dry years at each grid point using one standard deviation as a threshold.

\section{Results}

\subsection{Major moisture sources at seasonal scale}

Figure 3 shows the recycling ratio (hereafter RR), which is the fraction of moisture falling as precipitation in a specific grid cell that originated as evapotranspiration from the entire evaporative source region, over the target region ML for the four seasons: winter (December-January-February), spring (Mar-April-May), summer (June-July-August), and fall (September-October-November). Higher RR values mean that the moisture source domain is large enough to account for most of the precipitation moisture source. Alternatively, lower RR values mean that the moisture source domain is not sufficiently large enough to account for major moisture sources. In our analyses, the RR falls between 85 and 95\% for most of the seasons with the exception of small regions northwest of the Caspian Sea in all seasons, and parts of France and Spain in summer where the RR is below $80 \%$. Overall, higher RR values in our analyses suggest that the domain used for the identification of evaporative sources is suitably large.

We find that most of the moisture for seasonal precipitation comes from three main moisture sources, including the NA, MS and local recycling over the ML (Fig. 4). The first three columns in Fig. 4 show individual seasonal contributions from the NA, MS and local evapotranspiration

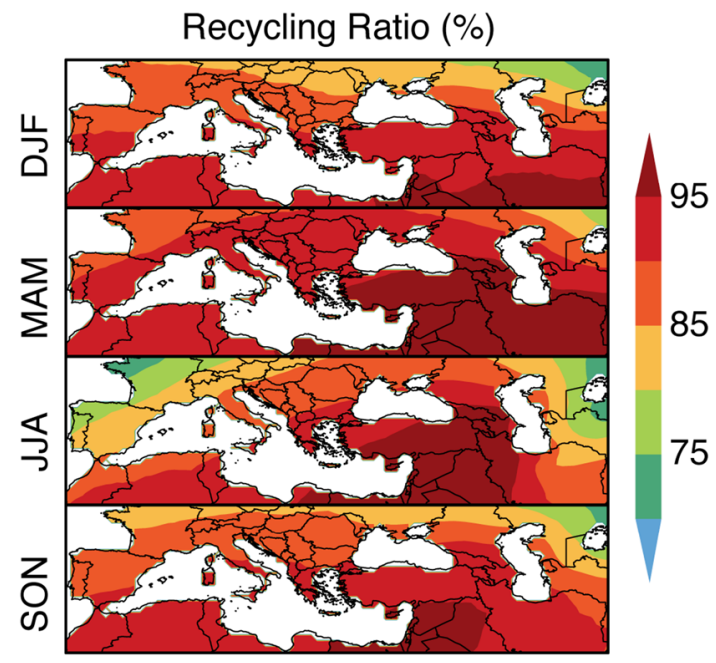

Fig. 3 The fraction (\%) of moisture falling as precipitation at each grid cell that originated as evapotranspiration from the evaporative source region

over the ML, while the fourth column represents the total contribution from the remaining seven source regions. Over the western part of the ML, moisture predominantly comes from the NA, which accounts for up to $65 \%$ of the total precipitation in winter and fall, and up to $50 \%$ of the total precipitation in spring and summer. The influence of the NA as a major moisture source progressively decreases going from west to east. On the other hand, moisture from the MS and local recycling over the ML are the major moisture contributors over the eastern half of the ML where predominant contribution comes from local recycling in spring and summer (up to 65\%) while the MS is the dominant contributor in the coastal regions and east-southeast parts of the ML (up to $45 \%$ ). Other moisture source region contribution is more noticeable over the north-northwestern parts of the ML. The limited influence of other source regions over rest of the ML is due to the fact that most of these regions are either very far off or are on the downwind side. Among these regions, moisture from the Black and Caspian Sea are one of the major contributors to the precipitation in their surrounding areas (not shown) in the north-northwest. Similarly, moisture intrusion from the Arabian Sea and South Asian land are limited to the western boundaries of the ML in the central Asian region due to topographic barriers and their downstream location.

When individual moisture contributions are calculated at monthly timescales (Fig. 5), we note the presence of intraseasonal variability in moisture transport from the major source regions, which is the lowest during winter (Figs. 5, 6). Moisture transport from the NA gradually intensifies during fall, which peaks in winter and then gradually weakens during spring and summer, finally reaching its lowest point 


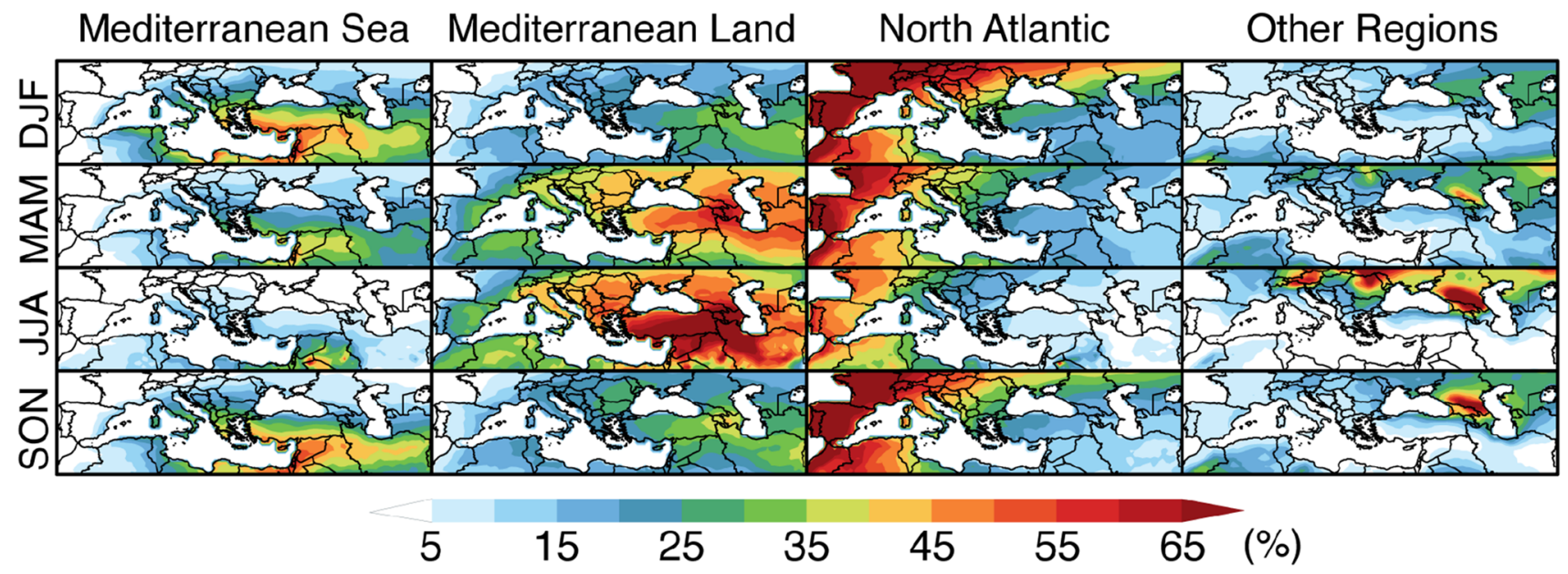

Fig. 4 Percent seasonal precipitation contribution from the Mediterranean Sea (first column), Mediterranean land/local recycling (second column), North Atlantic (third column) and sum of the contribution from remaining seven evaporative source regions (fourth column)

in July. While the annual cycle of moisture contribution from the MS exhibits similar characteristics, its contribution to the westmost parts of the ML region remains $<5 \%$ in all months. Understandably, the dependence on local recycling is at its maximum when the moisture contribution from two other major moisture sources is the minimum and vice versa. The contribution from the rest of the source regions exhibits strong intra-seasonal variations during summer and fall over the eastern parts of the ML. The variations in moisture transport at sub-seasonal timescales has been noted in earlier studies where different events within the same season were driven by moisture contribution from distinct sources (Insua-Costa et al. 2019). Nonetheless, it is important to note that despite the monthly-scale variability in the moisture transport from individual sources, the order of moisture contribution from major moisture sources, identified using seasonal means, does not change. For instance, local recycling is the dominant mechanism for moisture both at seasonal and monthly scales during spring and summer over the eastern part of the ML. Likewise, the NA remains the dominant moisture provider over the western part of the ML during all months and seasons. Due to this general consistency in the order of moisture contribution from source regions, we use seasonal means for the rest of the analyses.

Given the east-west contrast in moisture sources over the study area, we zonally divide the ML region in two parts, one in mostly western Europe spanning from $9^{\circ} \mathrm{W}$ to $19.5^{\circ}$ $\mathrm{W}$ and one spanning from $19.5^{\circ} \mathrm{W}$ to $48.75^{\circ} \mathrm{W}$, and summarize seasonal contributions from various moisture sources over the eastern and western ML regions as domain averages (Fig. 7). As previously described in the spatial maps, the NA is the major provider over the western ML region in all seasons with the domain average contribution ranging between $43 \%$ in summer and $64 \%$ in winter. The local recycling contribution progressively increases in both regions from winter to summer and then decreases in autumn, likely due to seasonal variations in land surface temperature, which influence the rate of evapotranspiration. The MS is the next major contributor after local recycling over the eastern ML region, in addition to noticeable (5\% or higher) contributions from NE and BCS. The MS contribution remains 7\% or higher over the western half during the cold seasons.

\subsection{Interannual variability of moisture sourcing}

Using the previously defined eastern and western ML regions, we further investigate the relationship between precipitation variability and variations in the moisture contribution coming from four major source regions (NA, ML, MS, NE) at inter-annual timescales (Fig. 8). In Fig. 8, the pink line represents the range of standardized seasonal precipitation (minimum and maximum) in each year across four reanalysis datasets, the red and gray lines represent the standardized seasonal precipitation in the CRU and CHIRPS observations. We divide each time series with its standard deviation to compare them on a similar scale. We note that the spread across the four reanalysis' is quite small during the winter season, suggesting a general consistency across the datasets. However, there are more noticeable disagreements in their anomalies during relatively dry summer and autumn seasons. Nonetheless, the interannual seasonal variability in the reanalysis-based precipitation is quite similar to that in the CRU and CHIRPS observations with the exception of eastern ML in DJF where year to year correspondence between the observations and the reanalysis datasets is relatively low. The remaining four lines represent the interannual precipitation variability in each season due to changes in moisture contribution from the four previously 


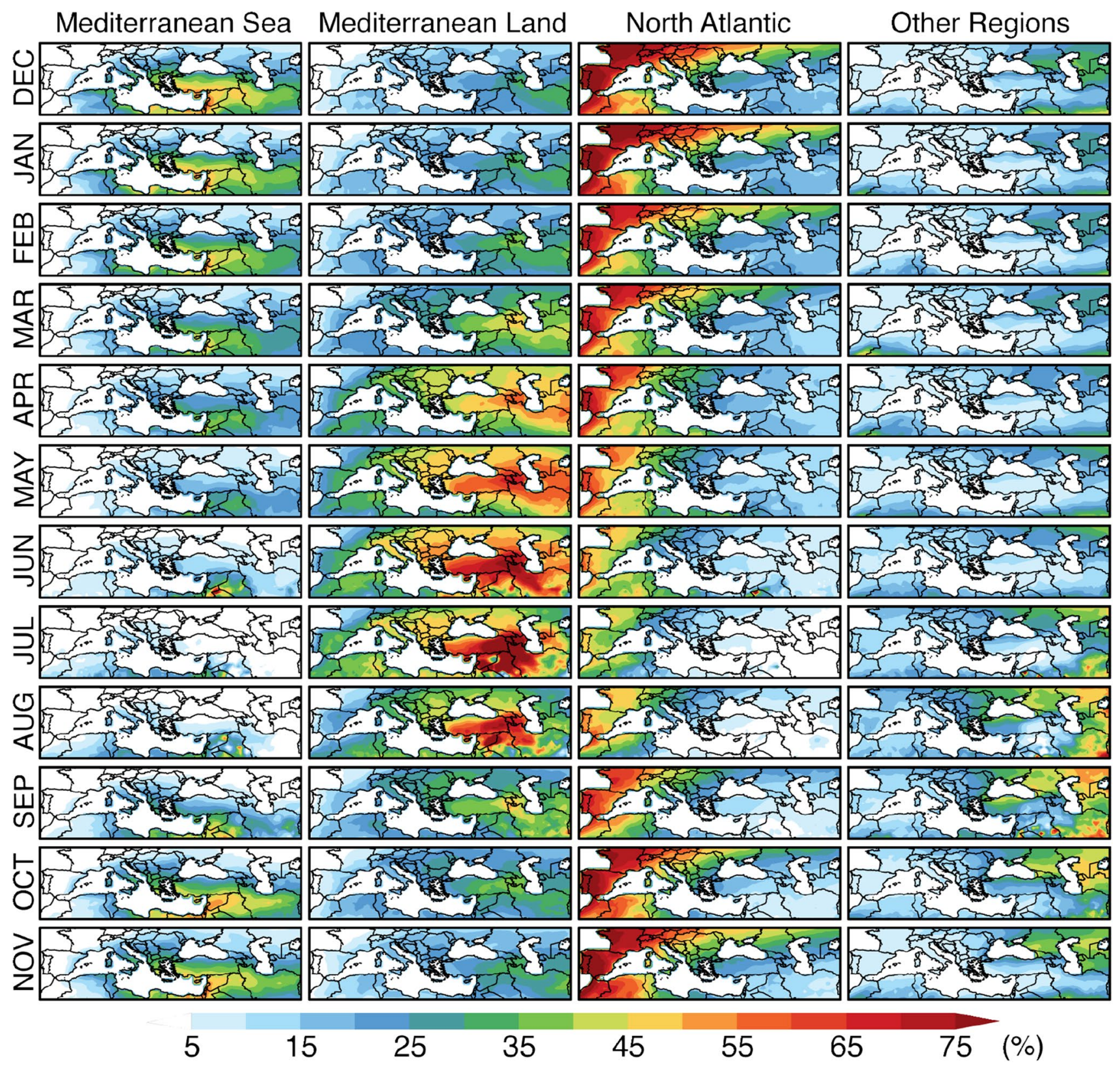

Fig. 5 Percent monthly precipitation contribution from the Mediterranean Sea (first column), Mediterranean Land/Local Recycling (second column), North Atlantic (third column) and sum of the contribution from remaining seven evaporative source regions (fourth column)

mentioned moisture sources. Additionally, the numbers at the bottom (top) in each panel represent the correlation between the CRU (CHIRPS) observations and timeseries of each moisture source contribution with an asterisk representing a significant correlation at a 95\% confidence level. The numbers in pink represent the correlation between the ensemble mean of reanalysis and the observations (CRU and CHIRPS). These correlations are not very sensitive to the choice of the observational dataset with the exception of the eastern ML region in winter where a relatively lower correlation (NE; CHIRPS: $-0.37 *$, CRU: -0.26 ; NA; CHIRPS: 0.30 CRU: 0.56*) reflects less correspondence among datasets. Over the western ML region, the interannual precipitation variability closely resembles the interannual variability in the moisture contribution from the NA, while the variability of moisture contribution from the MS has the strongest influence on the precipitation variability over the eastern ML region. Precipitation variability is more closely associated with the evapotranspiration over the land regions (ML and NE) over the eastern half during summer 


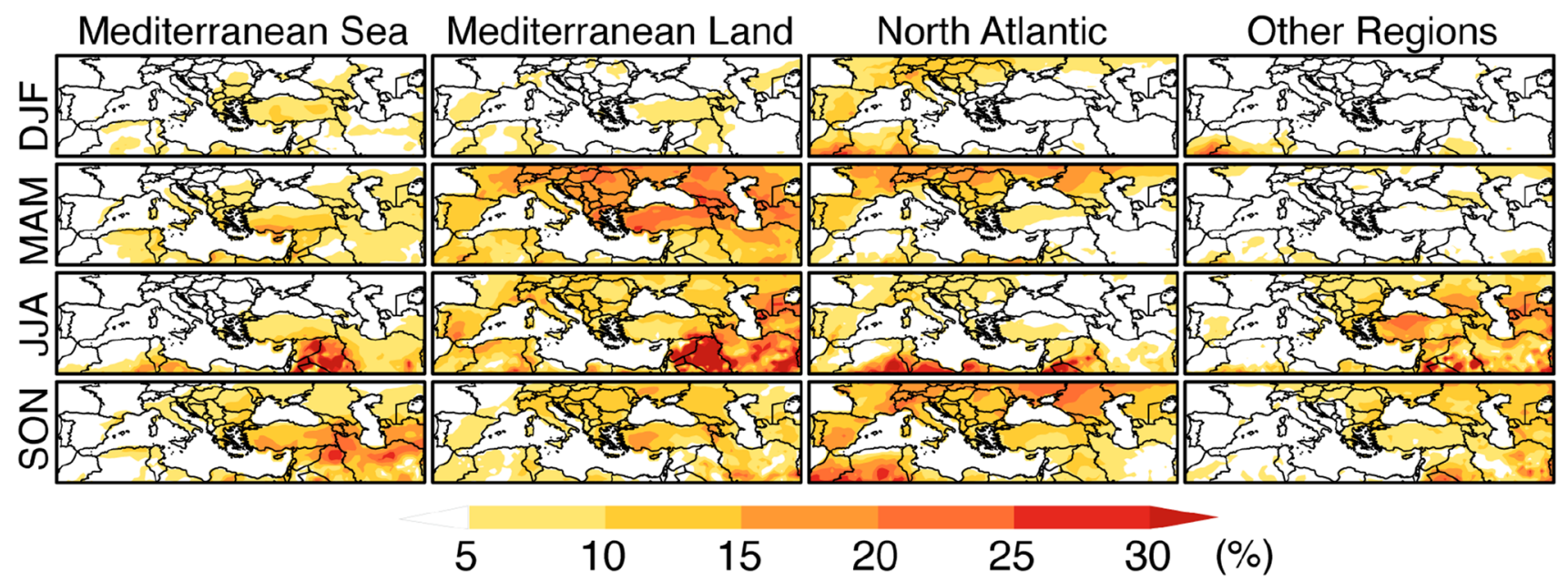

Fig. 6 Difference between the seasonal maximum and the seasonal minimum in the percent precipitation contribution from the Mediterranean Sea (first column), Mediterranean land/local Recycling (sec- ond column), North Atlantic (third column) and the rest of the seven evaporative source regions (fourth column)

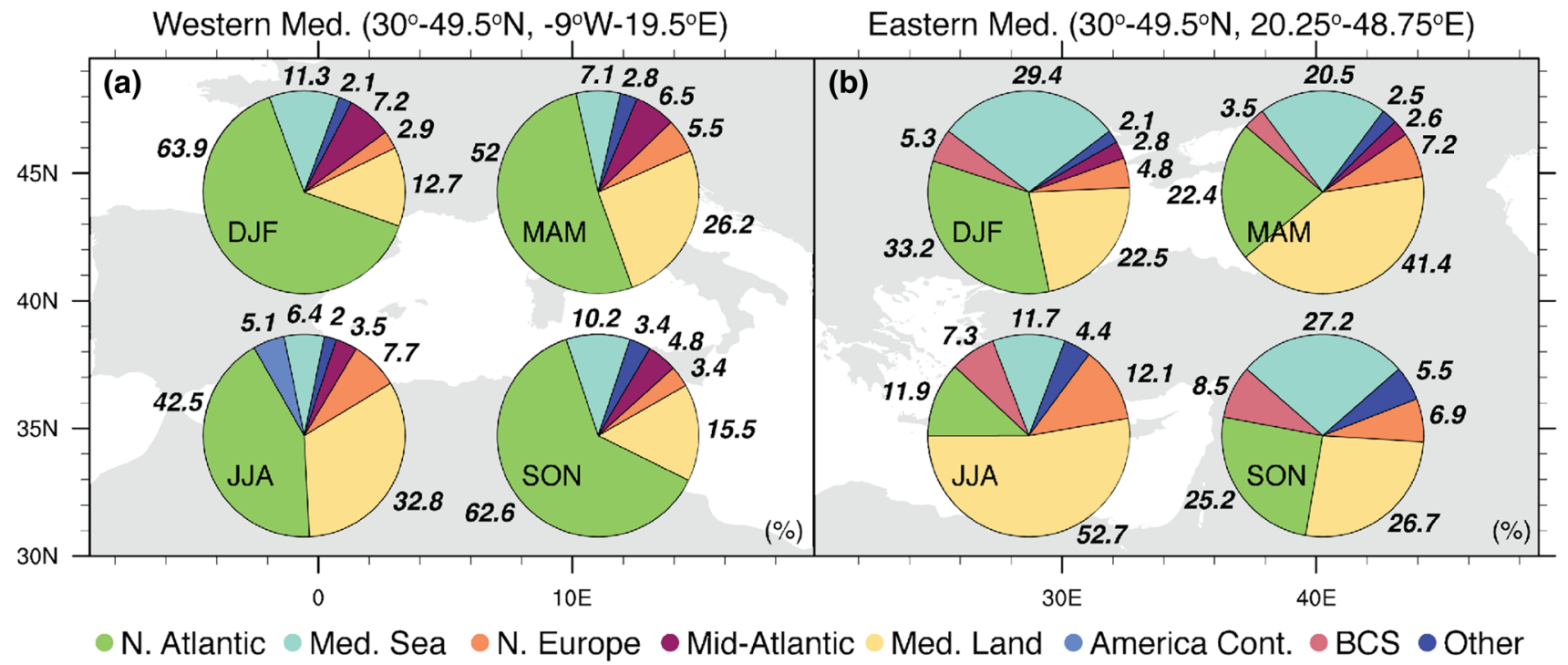

Fig. 7 Percent contribution from the major moisture sources to the total precipitation in a Western Mediterranean Land region, b Eastern Mediterranean land region

and autumn. However, the moisture contribution from the $\mathrm{NE}$ is negatively correlated with precipitation over the eastern ML region in winter.

Qualitatively, we note mostly consistent anomalies in moisture transport from major sources during dry years. For instance, over the western ML region, significant low precipitation years, such as 1985 fall, 1992 winter, 2003 spring and summer, exhibit substantially less moisture transport from the NA. Similarly, over the eastern ML region, anomalously dry years, such as 1986 spring, 1989 and 2008 winter, and 1990 fall, exhibit a reduced moisture supply from the MS and ML.

\subsection{Moisture sourcing during extreme wet events}

During extreme precipitation events, defined at each grid point as the days when precipitation magnitude crosses the grid-based $95 \%$ percentile of daily precipitation during the analyses period (1980-2013), number of robust patterns of anomalies (with respect to the climatological mean) emerge regarding the contribution of moisture from major sources. However, an exception exists in winter that exhibits little agreement among the reanalysis. Compared to the climatological mean, a robust increase (up to $>30 \%$ ) in moisture from the MS is seen over most 


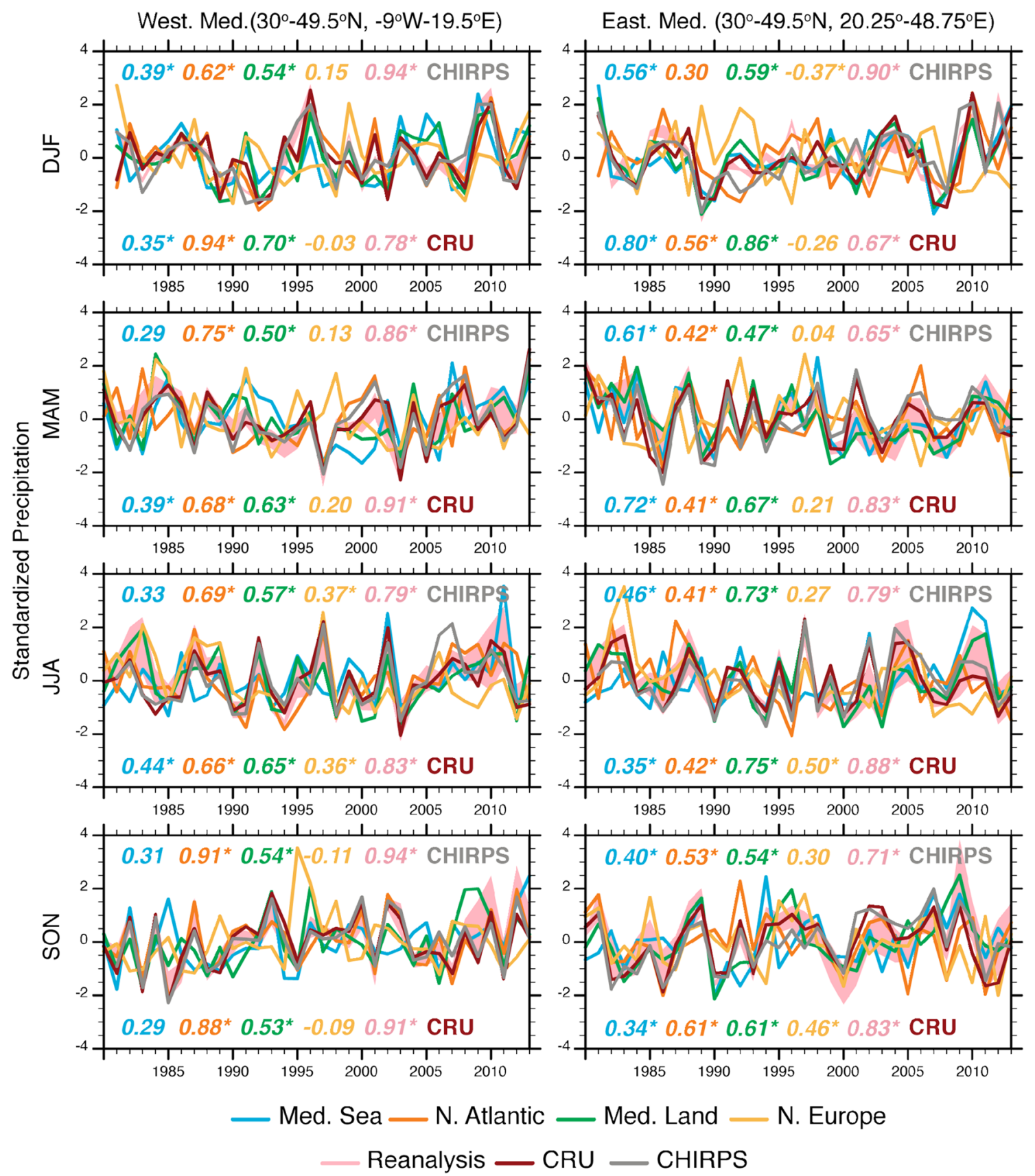

Fig. 8 Inter-annual variability of domain averaged standardized precipitation over the eastern and the western ML regions in the CRU (red), CHIRPS (grey) observations, contributions from the Mediterranean Sea (blue), North Atlantic (orange), Mediterranean Land (green), and Northern Europe (yellow). The pink line represents the spread of precipitation variability in the four reanalysis datasets.

of the Balkan Peninsula and eastern ML regions in all spring, summer and fall seasons. On the other hand, the most robust positive moisture anomalies from the NA during extreme precipitation events are witnessed over the western half of the ML and parts of southeast. Interestingly, moisture form the NE, and BCS exhibit negative
The numbers at the bottom (top) in each panel represent correlation between the CRU (CHIRPS) observations and each timeseries with asterisk representing significance at $95 \%$ confidence level. Numbers in pink show the correlation of the ensemble mean of the four reanalysis datasets with the CRU observations

anomalies (up to $>20 \%$ ) during precipitation extremes over most of the ML in all three seasons with the exception over parts of northwest in fall. Similarly, a decrease in the contribution from the local recycling of moisture during extreme events is seen over the southern half of the ML, pointing towards significant role of oceanic 
moisture sources (MS and NA) in the case of precipitation extremes over these regions. Anomalous moisture contribution from other sources plays a role over the southern half of ML region during spring and fall with an increase up to $>30 \%$. It is unclear why the reanalysis datasets have little agreement in moisture anomalies during extreme precipitation events in winter despite the fact that the spread among the reanalysis is the minimum at area averaged seasonal timescales (Fig. 9).

\subsection{Spatial trends in moisture sources}

Observed seasonal precipitation exhibits spatially heterogenous trends at seasonal timescales, which are generally insignificant during our analysis period (1980-2013) with the exception of the parts of the northwest ML region where CHRIPS observations exhibit a significant increase in winter, spring and fall (Fig. 10). Both CRU and CHRIPS observations exhibit mostly positive but insignificant trends over the Balkan Peninsula and Italy in fall and winter, and negative over the western parts of ML region in winter. Moreover, a general drying is observed over eastern Europe and southern ML regions in summer and mixed trends over the Balkan and western ML regions. The two observations disagree in the spatial distribution of seasonal precipitation trends over the parts of southeastern ML in winter and spring where CHRIPS exhibits increasing trends while CRU exhibits decreasing trends. The four reanalysis datasets are largely consistent in the representation of the observed trends in winter and fall both in terms of magnitude and spatial distribution. Additionally, they capture negative trends over eastern Europe in summer. However, the magnitude of their trends is substantially stronger particularly in the case of CFSR and MERRA. Most of the reanalysis also exhibit negative trends over the parts of eastern Europe in spring, which are opposite to those in the observations. It is important to note that spatial trends across the reanalysis datasets are more consistent than the spatial trends across the observations. Such a consistency in the reanalysis is useful as it can potentially help to establish a robust understanding towards the variability in the moisture sources that drive these trends.

In order to understand the role of different moisture sources in shaping the seasonal trends observed in the reanalysis datasets, we analyze trends in the moisture transport from major source regions (first three column in Fig. 11) and the rest (last column in Fig. 11) for each season. An increase in the precipitation over the Balkan Peninsula and surrounding regions during fall and winter is driven by enhanced moisture transport from the MS and NA, as well as by stronger local recycling over the ML. Additionally, there is a decrease in moisture transport from the NA over parts of western Europe and eastern ML regions in winter, which dictates the spatial pattern of precipitation. Reduced moisture transport from the MS and NA during spring and from the NA during summer over parts of the ML not only reduces their contribution to the seasonal moisture but also limits the amount of moisture that can be sourced from land regions. Similarly, reduced precipitation over terrestrial regions negatively impacts the moisture availability through

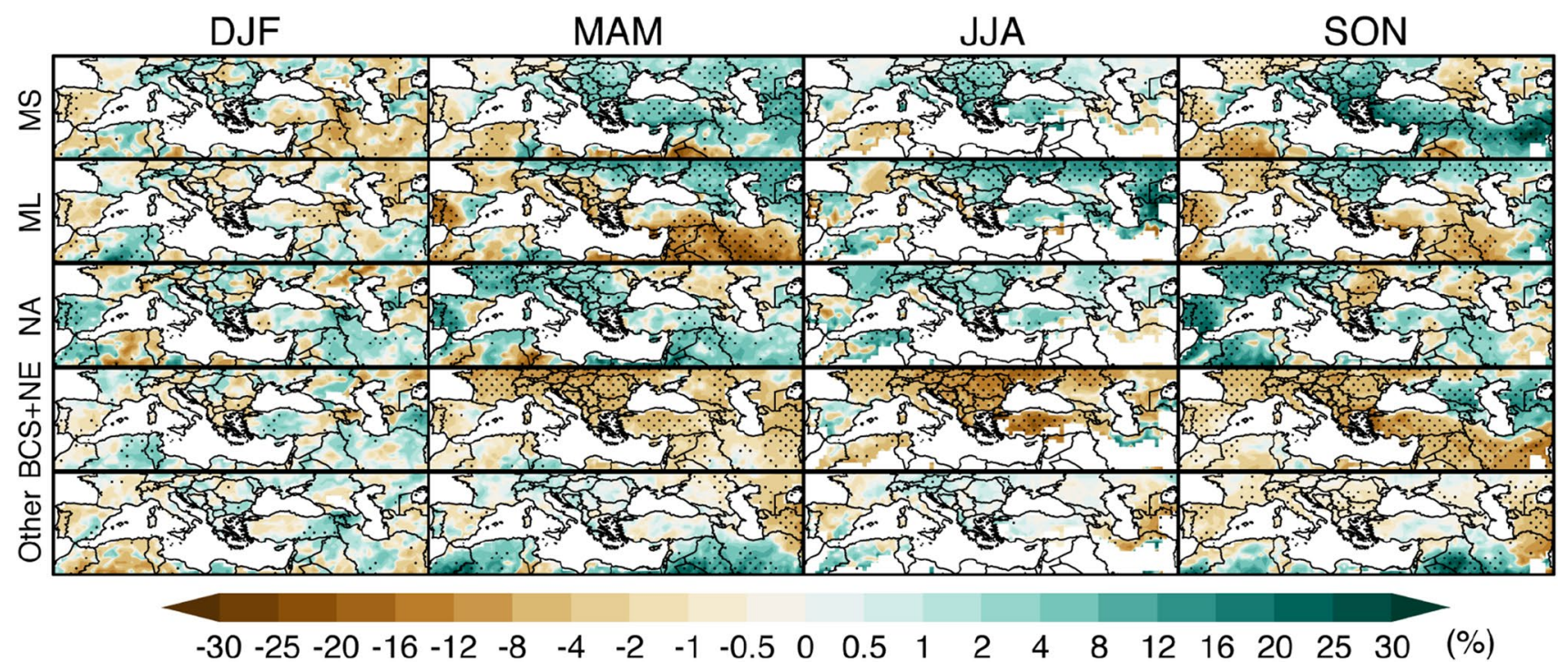

Fig. 9 Seasonal anomalies in moisture contribution during daily extreme precipitation (above 95th percentile) from the Mediterranean Sea (first row), Mediterranean land/local recycling (second row), North Atlantic (third row), sum of Northern Europe and Caspian and Black Seas (fourth row), and the sum of the rest of six evaporative source regions (fifth row). Stippling in each panel represents the robustness of anomalies across the four reanalysis datasets 


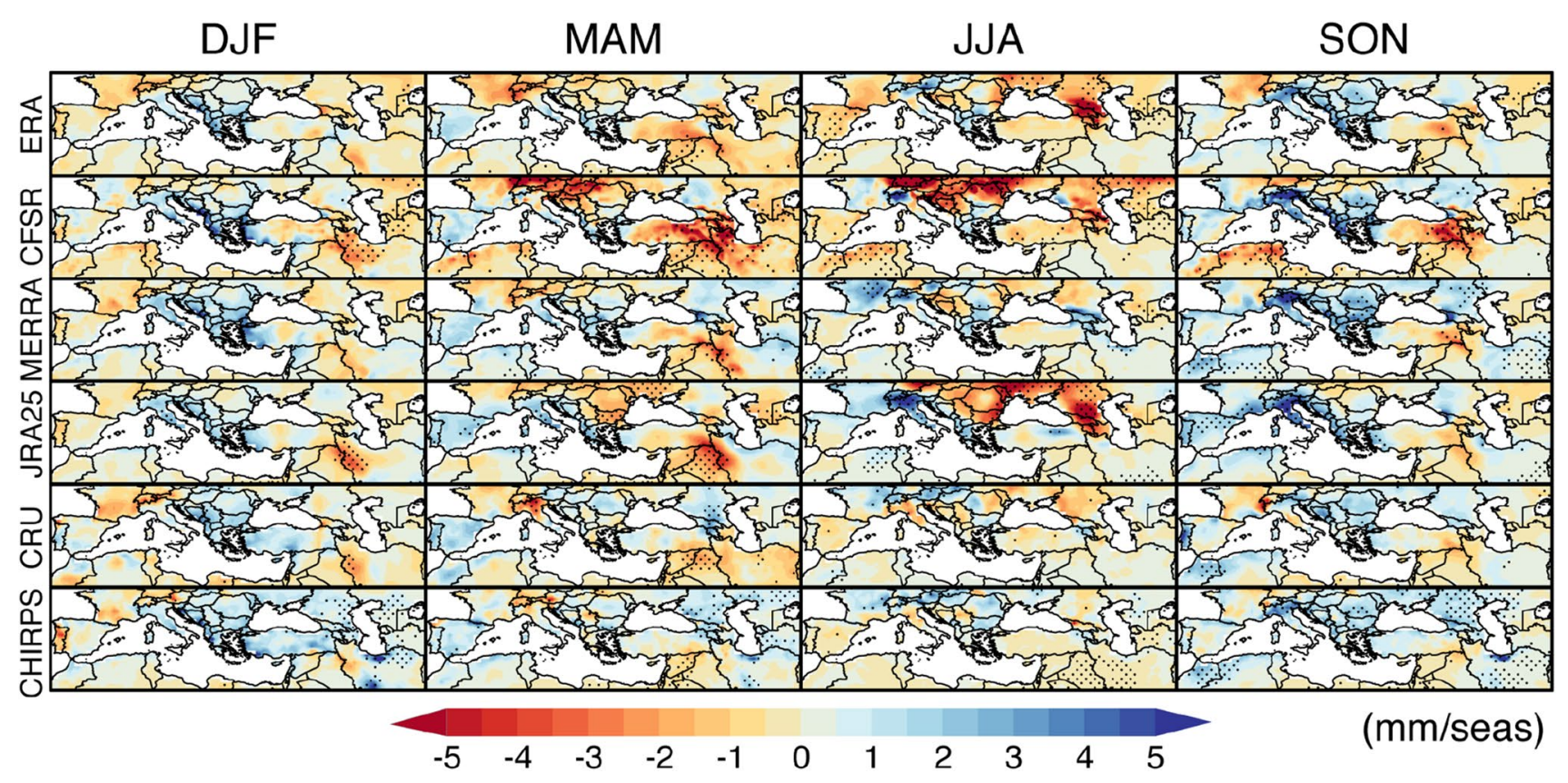

Fig. 10 Seasonal precipitation trends per year in the four reanalysis and the observations. Stippling in each panel represents the significance of trend at $95 \%$ confidence level

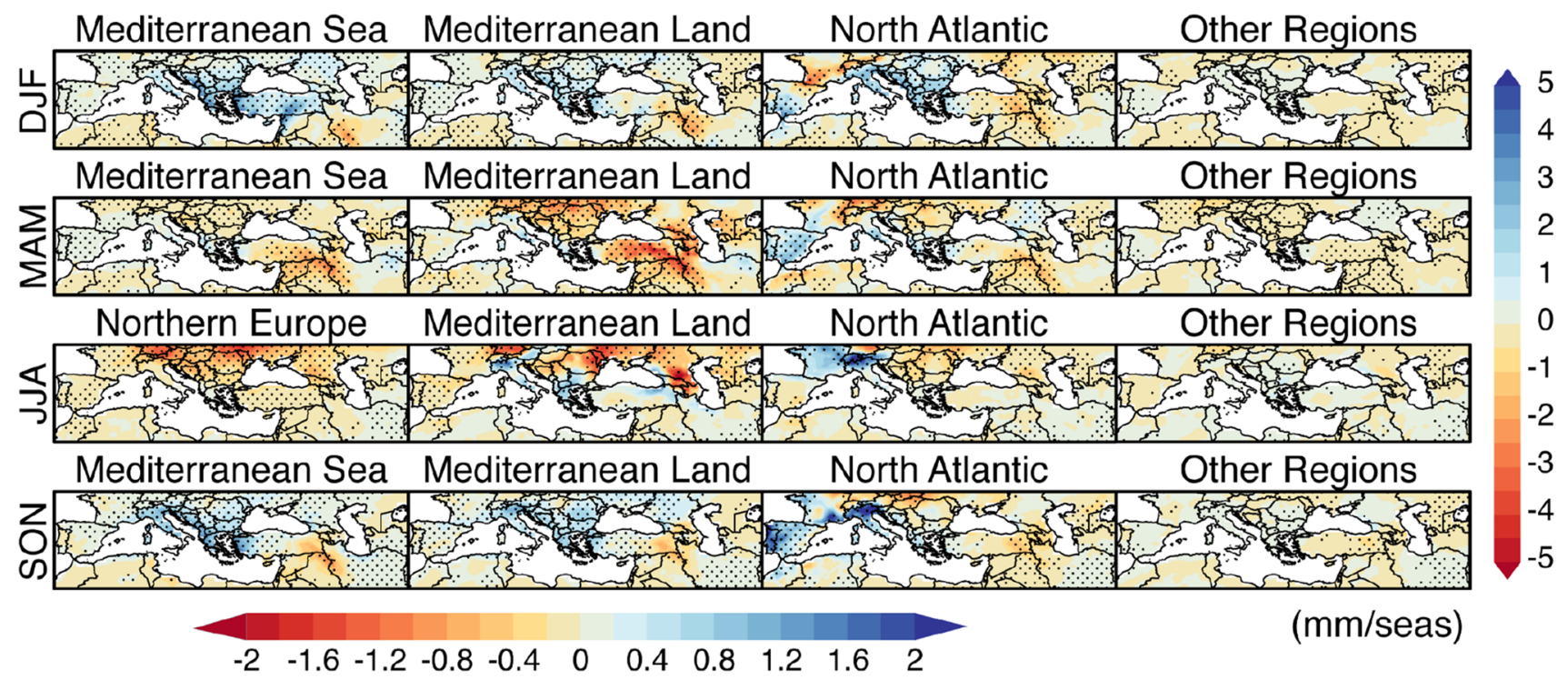

Fig. 11 Seasonal trends per year in moisture contribution from the Mediterranean Sea (first column), Mediterranean land/local recycling (second column), North Atlantic (third column) and the rest of the

evapotranspiration after it falls as precipitation. It is perhaps due to these reasons that local recycling over the ML and moisture contribution from the NE exhibits strong decreases over those parts of the ML that receive low contributions from the MS and NA and show strong negative precipitation trends in the reanalysis. While the four reanalysis datasets seven evaporative source regions (fourth column). Stippling in each panel represents the agreement among the reanalysis datasets

largely agree regarding the drivers of most noticeable seasonal trends, they tend to disagree more in the moisture contribution trends from the NA than any other major moisture source. Additionally, the agreement among the reanalysis datasets is generally less in summer particularly over the southern half of ML region (Fig. 11). 


\subsection{Influence of remote forcing on moisture supply}

Figures 12, 13, 14 and 15 show seasonal magnitude of anomalies for those regions that show a noticeable increase or decrease in moisture contribution. The first four columns represent the top four anomalous contributors while the last column represents the overall (sum of all regions) anomaly. Stippling in each panel represents the robustness of anomalies across the four reanalysis datasets.

The NAO is the most significant large-scale forcing that exerts influence on the precipitation distribution over the ML region through variations in moisture sourcing from various evaporative sources (Hurrell 1995). During the negative phase of NAO (NAO-N), most of the ML experiences a noticeable increase in seasonal precipitation during winter (Fig. 12). The positive influence of NAO-N stretches into spring over the northern half of the ML while the southern half begins to witness a negative influence. During the summer season, the NAO-N influence is more complex, with a decrease in precipitation over the Balkan and northcentral parts of the ML and an increase in precipitation over higher elevations and surrounding areas in the Alps and Caucasus. During the fall season, the NAO-N influence is generally positive, with the exception of the eastern region of the Mediterranean Sea. The positive phase of NAO (NAO-P) is mostly opposite to the influence of NAO-N during all seasons with the strongest influence in terms of precipitation anomalies exhibited during winter and fall (Fig. 13). A notable exception exists over Turkey in spring where the sign of anomaly is similar in both phases, though the anomalies are more robust in NAO-P.

The positive phase of ENSO (El Niño) exhibits an east-west dipolar influence on the ML region during winter and spring seasons with a decrease in precipitation over the western ML region and an increase in precipitation over the region east of the Mediterranean Sea (Fig. 14). During the summer season, El Niño exerts a predominantly positive influence with the exception of the Balkan region, which shows a negative precipitation anomaly. Such a negative influence of El Niño further expands to northern and north-eastern parts of the ML region during fall seasons while other regions within the ML exhibit a positive change. Compared to El Niño, the spatial footprint of the negative phase of ENSO (La Niña) is relatively small (Fig. 15). Interestingly, La Niña exhibits similar negative influence on western parts of the ML region in winter and the Balkan region in summer. Another strong spatial footprint of $\mathrm{La}$

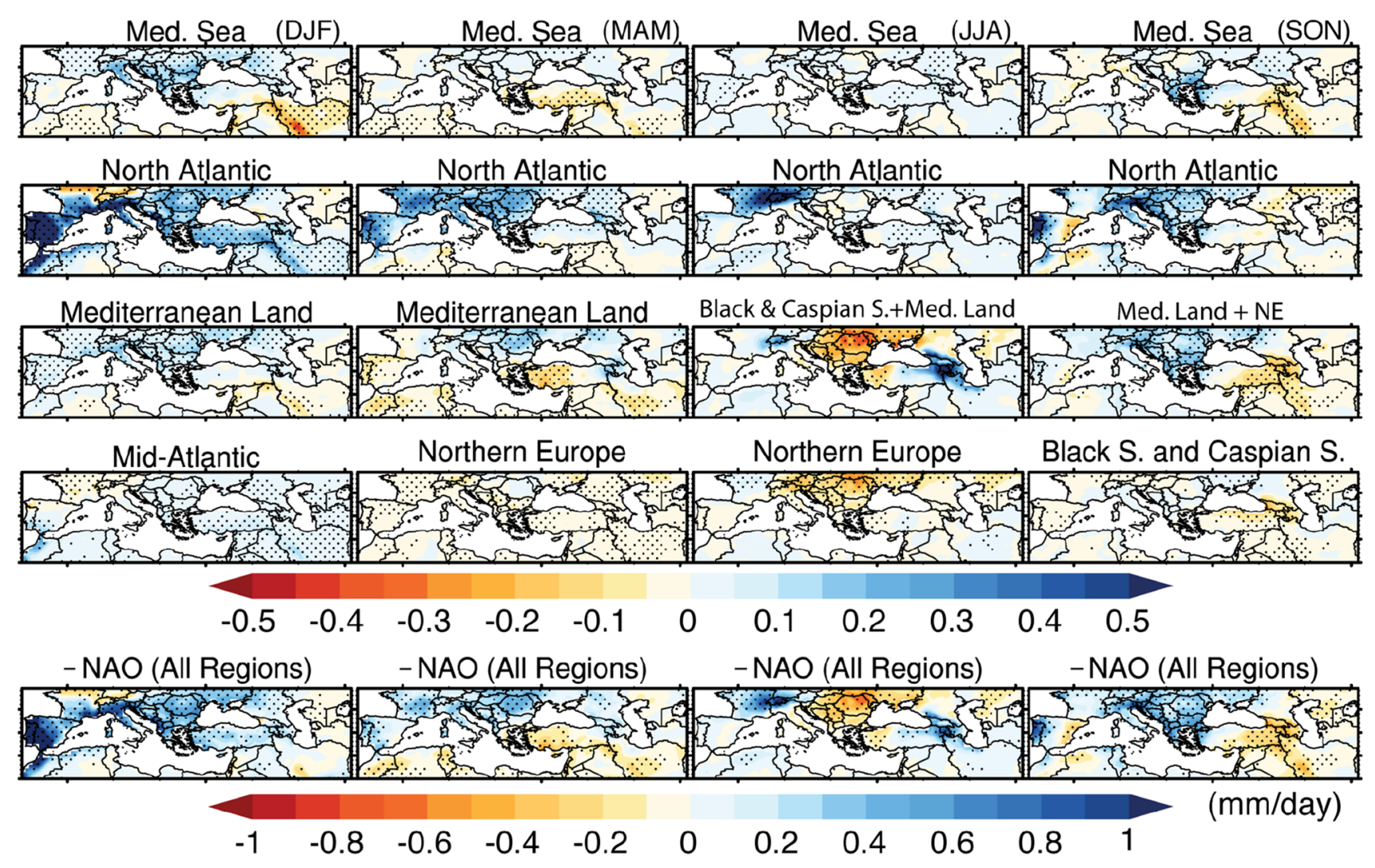

Fig. 12 Composite of seasonal anomalies in precipitation contribution during years with the negative phase of NAO. Anomalies are shown for those source regions where they are most noticeable. Stip- pling in each panel represents the robustness of anomalies across the four reanalysis datasets 


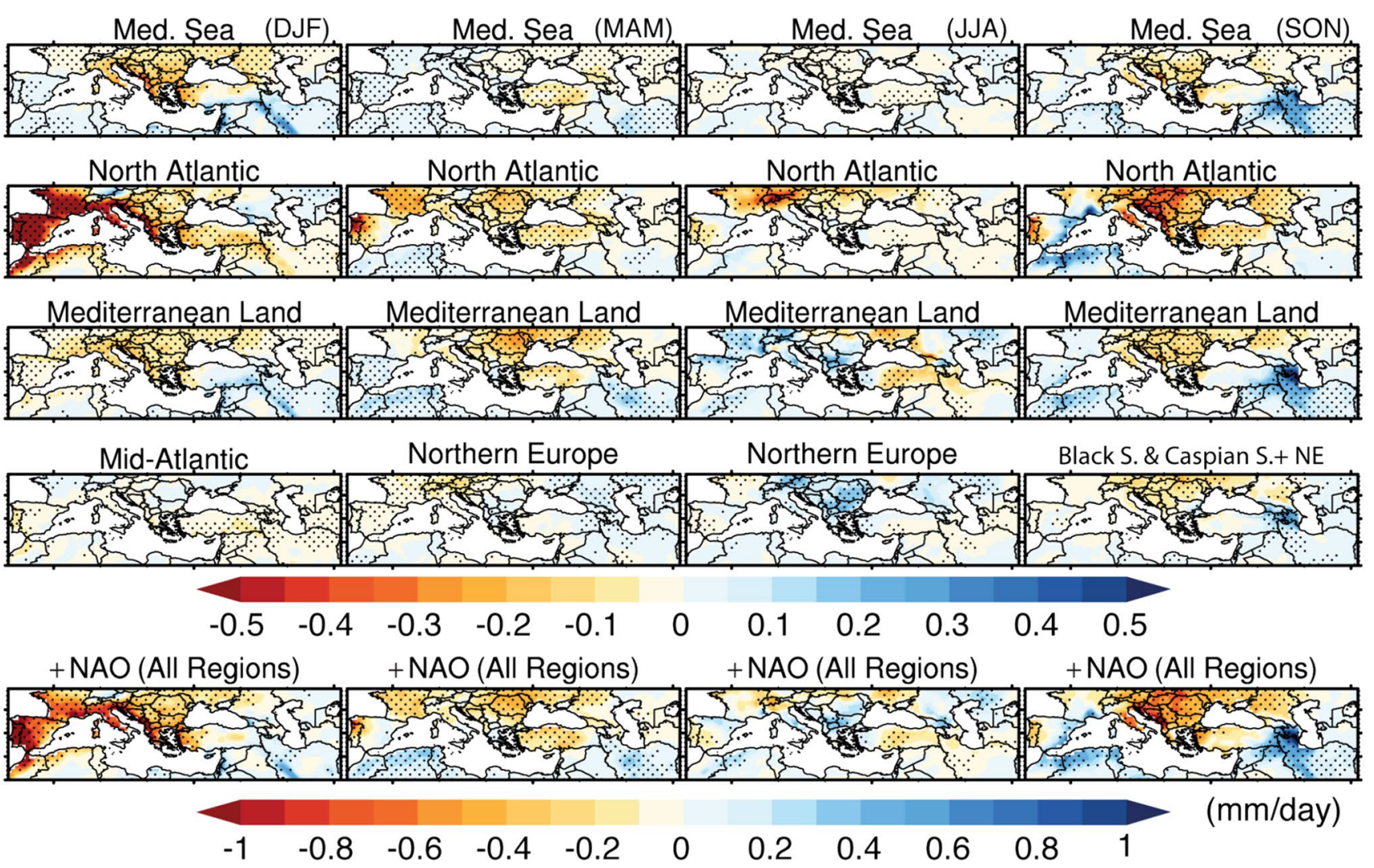

Fig. 13 Same as in Fig. 12 but for the years with the positive phase of NAO

Niña, in addition to winter, is seen in spring when it exhibits a northwest-southeast dipolar influence with positive precipitation anomalies in the northwest and opposite anomalies in the southeast over the ML region. The negative influence of $\mathrm{La}$ Niña in winter comes mostly in the form of reduced moisture contribution from the North Atlantic region. Some reduction is also exhibited in the moisture contribution from the MS.

\section{Discussion}

The NAO is the major large-scale forcing that exerts influence on precipitation variability over the Mediterranean region (Hurrell 1995; Gómez-Hernández et al. 2013; Mariotti et al. 2002; Sen et al. 2018; Xoplaki et al. 2004). During the NAO-N, storm tracks move southward in winter, which allow for more onshore flow from the NA and MS and less moisture contribution from the NE, which results in net positive precipitation responses that progressively diminish going from east to west. Similar types of anomalies persist with some variation in their spatial pattern and relatively lower magnitudes in the other three seasons. Alternatively, an anomalously high sea level pressure over the NA in winter stretches over the MS and reduces the moist flow from these two sources over the ML during the NAO-P phase. It is important to note that lower-level $(850 \mathrm{mb})$ circulations and sea level pressure anomalies are comparable during wet years and the NAO-N, and during dry years and the NAO-P over the northern half of the ML that clearly demonstrates the major footprint of the NAO on the seasonal precipitation variability over the ML (Figs. 16, 17). These dynamic and thermodynamic influences of the NAO on the Mediterranean climate have been consistently reported in earlier studies (Dünkeloh and Jacobeit, 2003; Kelley et al. 2012; Maheras et al. 1999; Raymond et al. 2018; Wanner et al. 1997; Xoplaki et al. 2004).

Compared to the NAO, the ENSO footprint on the Mediterranean climate variability is not only relatively small but is also less understood. Many studies have focused on the ENSO influence on the Mediterranean (Alpert et al. 2006; Brönnimann 2007; Brönnimann et al. 2006; Kadıŏlu et al. 1999; Mariotti 2002; Price et al. 1998; Shaman and Tziperman 2011; Xoplaki et al. 2002, 2004, 2012) with some suggesting that the El Niño and La Niña influence is very similar to the NAO-N (NAO-P) during late winter in the parts of the western Mediterranean (Brönnimann, 2007; Brönnimann et al. 2006; Zanchettin et al. 2008). However, our moisture source analyses do not provide any strong evidence in this regard. For instance, 


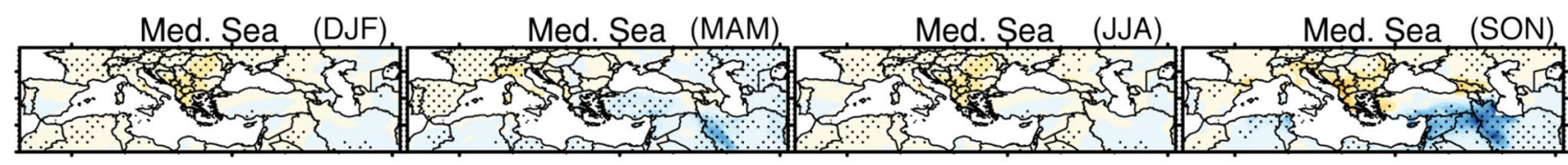

North Atlantic

North Atlantic

North Atlantic

North Atlantic

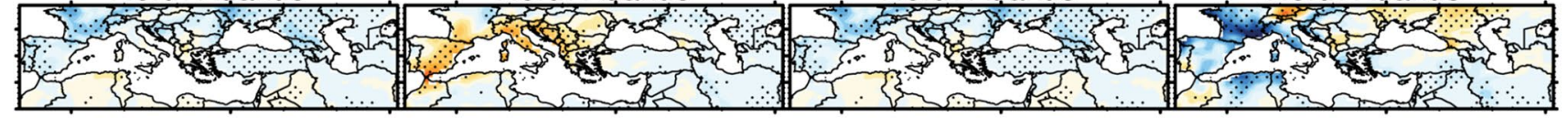

Mediterranean Land

Mediterranean Land

Mediterranean Land

Black \& Caspian S.+Med. Land
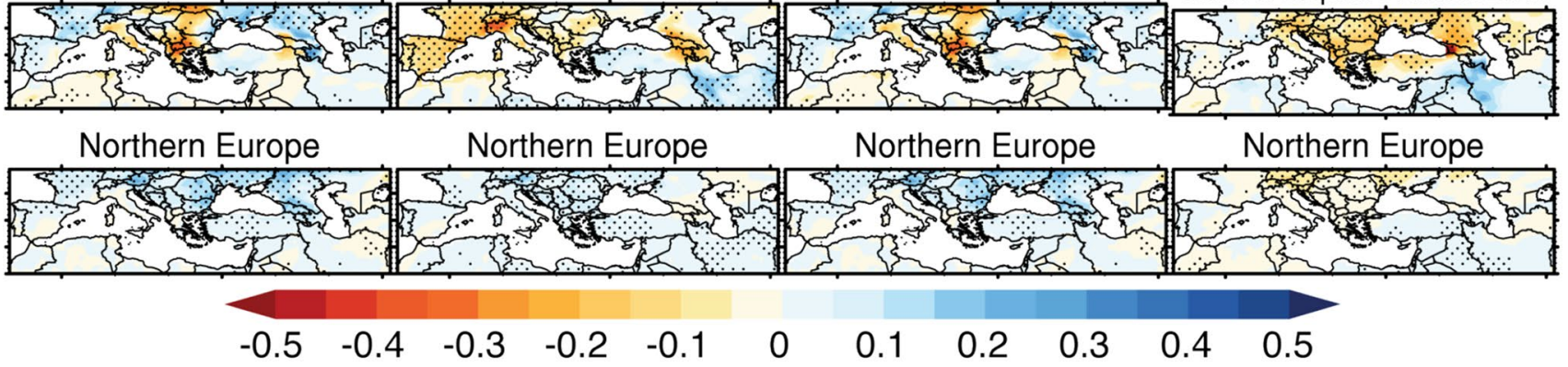

El Niño (All Regions)

El Niño (All Regions)

El Niño (All Regions)

El Niño (All Regions)

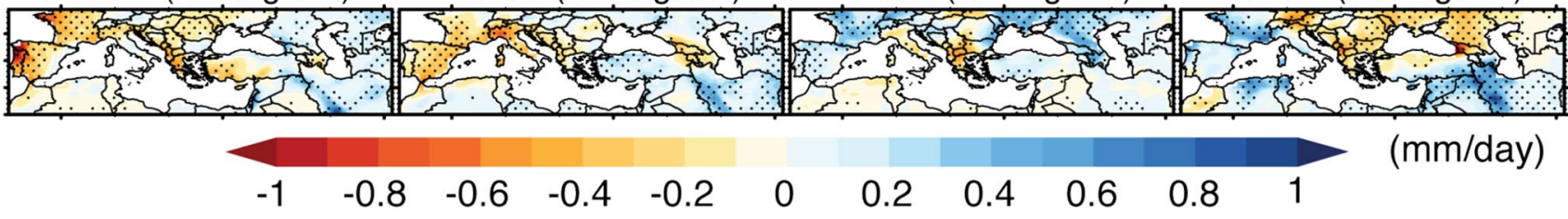

Fig. 14 Same as in Fig. 12 but for the El Niño years

we find similar precipitation and circulation responses during both phases of the ENSO (Fig. 18) over western parts of the ML as lower level circulations and sea level pressure anomalies in the El Niño, La Niña and dry years exhibit similarities. Similarly, moisture anomalies in the NAO-N and La Niña are similar during spring from the NA and local recycling and during fall from the MS. Similarly, there are clear similarities between the El Niño and NAO-P in terms of local recycling anomalies during all seasons. On the other hand, the eastern ML region exhibits positive anomalies during the El Niño and negative anomalies during the La Niña. Some studies suggest enhanced (reduced) moisture contribution from the Arabian Sea during winter over South and Central Asia during the El Niño (La Niña) (Mariotti 2007; Sandeep and Ajayamohan 2018), which is perhaps why the eastern Mediterranean exhibits positive (negative) anomalies as more moisture penetrates through the eastern and southeastern boundaries of the ML region. In any case, the lack of quantifiable evidence supporting the ENSO influence on the ML region in our analysis does not necessarily discredit the evidence provided by the earlier studies as there are differences between the seasonal time periods used in this study and earlier studies that might have an influence on the outcomes.

While our analyses are mostly limited to synoptic and seasonal scales, there are indicators that suggest the influence of other regional-scale mechanisms that may have a role in fine-scale variability of moisture transport in both space and time. For instance, the lack of moisture contribution from the MS to the west-northwest of the ML region is likely due to the Alps acting as an orographic barrier. On the other hand, excessive moisture transport from the MS to central and eastern Europe during extreme events in our analyses may be linked to the mesoscale forcing such as cut-off lows that have been known to cause precipitation extremes over the Mediterranean (Awan and Formayer 2017; Volosciuk et al. 2016).

\section{Summary}

Using a Lagrangian moisture back trajectory analysis, we investigate the contribution of terrestrial and oceanic evaporative sources to seasonal precipitation over the ML. While our analyses suggest a significant role of moisture 


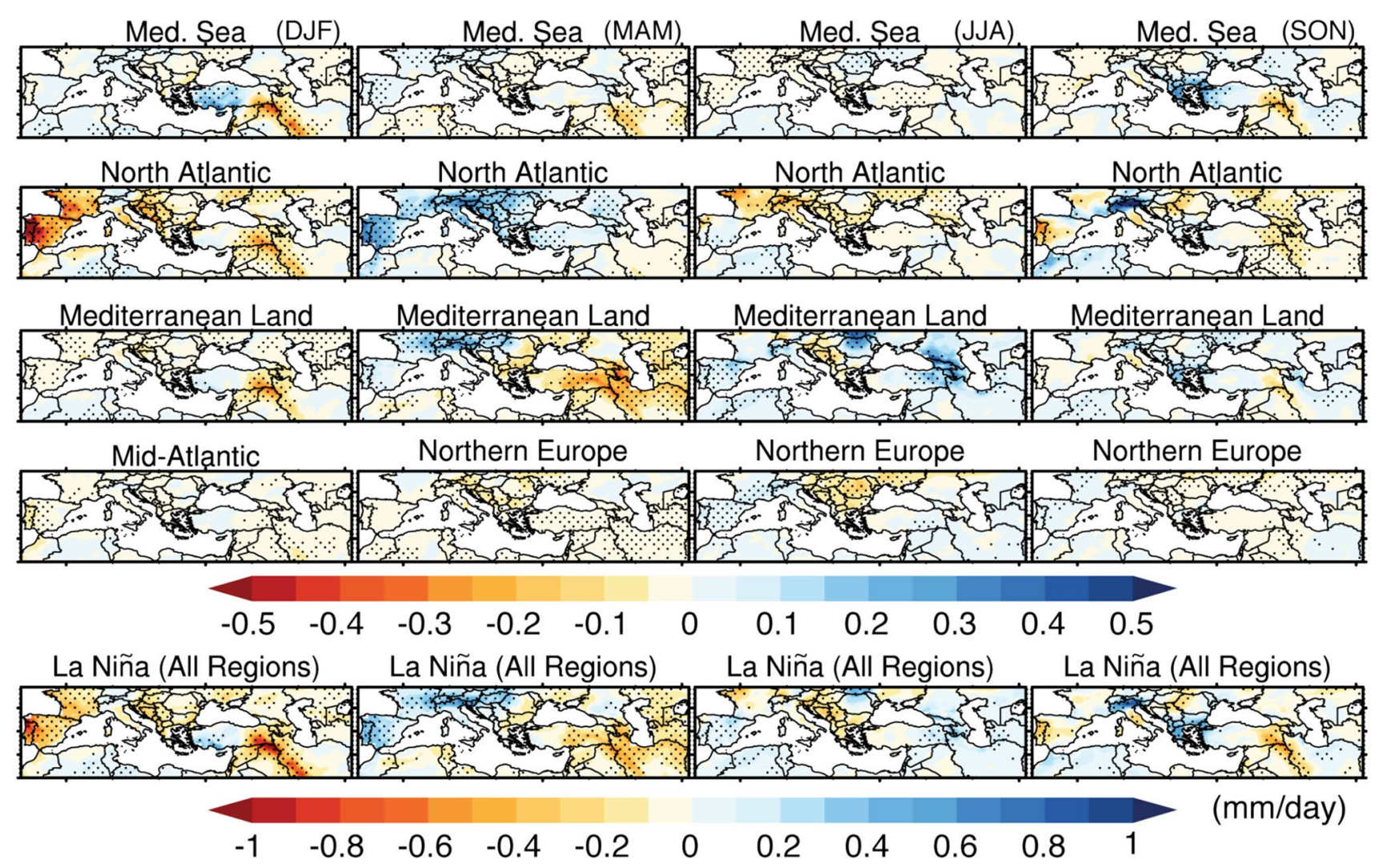

Fig. 15 Same as in Fig. 12 but for the La Niña years

advection from the NA and MS, and the local moisture recycling over the ML, a clear east-west contrast is visible in the relative importance of these moisture sources across different seasons. Moisture from the NA dominates precipitation variability over the western Mediterranean whereas moisture from the MS and ML majorly influence precipitation over the eastern Mediterranean. The moisture contribution from source regions exhibits intra-seasonal variability, but it does not impact the ranking of moisture sources, established using the seasonal means. Moreover, excessive moisture supply from major oceanic sources (NA and MS) plays a major role during daily precipitation extremes. Our analyses also reaffirm that the NAO is the most dominant large scale forcing as both dynamic and thermodynamic anomalies during the negative and positive phases of NAO correspond well with the anomalies during wet and dry years. The ENSO influence on the other hand is relatively weak and less robust. Evaporative sources and their inter-annual variations are generally robust across all four reanalysis datasets, however, relatively less robustness is witnessed across the reanalysis regarding sources of anomalous moisture supply in the case of winter extremes.

Despite a number of robust findings in our study, many caveats still need to be addressed. For instance, a better knowledge of uncertainties associated with evaporation estimates in the reanalysis data and their influence on the moisture source analysis is needed. Datasets, such as those based on The Global Land Evaporation Amsterdam Model (Martens et al. 2017), can be useful in this regard in the quantitative estimates of errors in the reanalysis products. Similarly, a lack of robustness in the precipitation trends in different observational datasets requires rigorous examination to determine the underlying causes. The robustness of moisture sources at higher temporal scales is also a challenge in the reanalysis datasets that warrants a thorough investigation. Nonetheless, this study improves our understanding of the thermodynamic influence of neighboring oceanic and terrestrial regions on the Mediterranean climate and should help to better interpret precipitation variability and future precipitation responses due to internal and external forcing. 


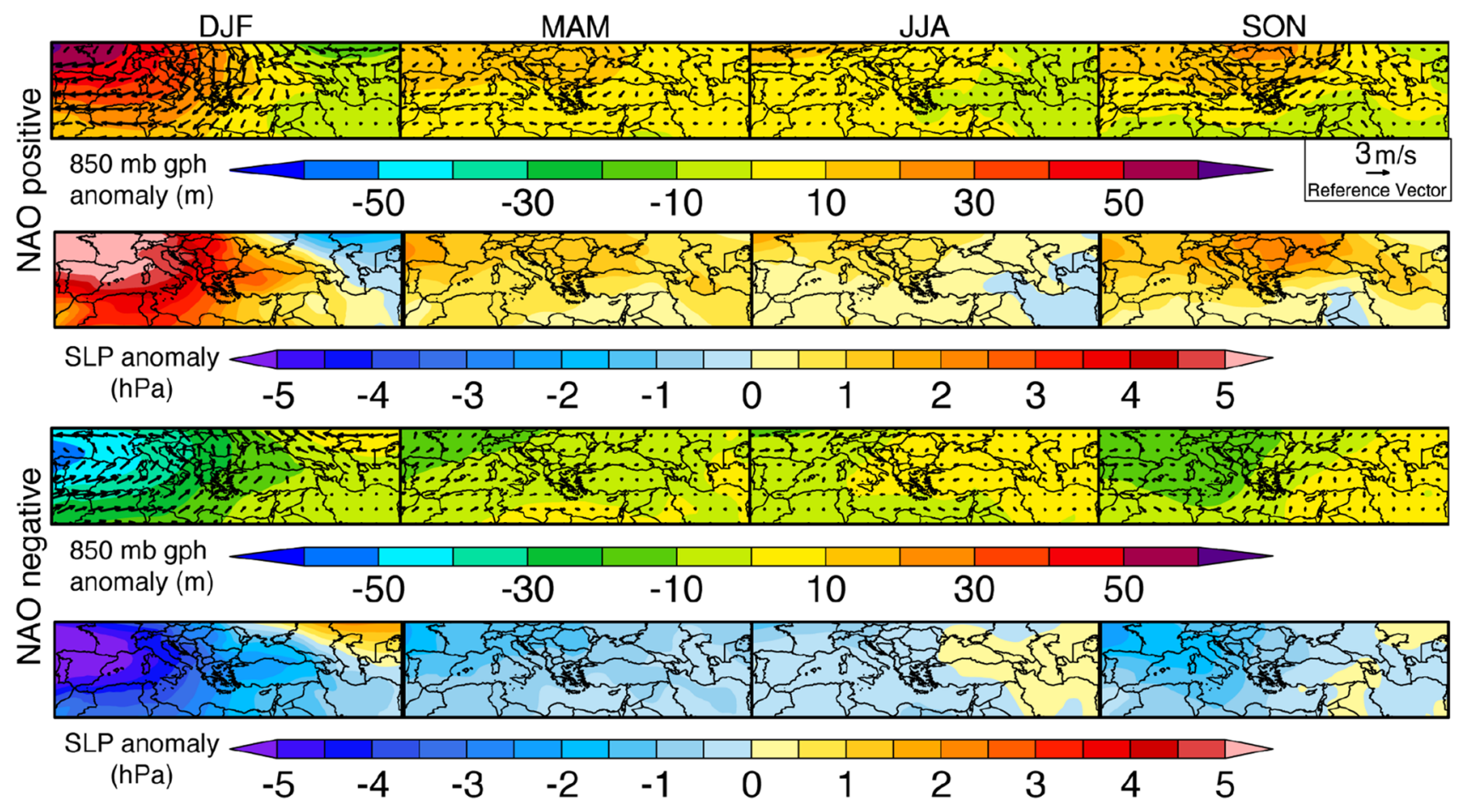

Fig. 16 Composite of seasonal anomalies in $850 \mathrm{mb}$ winds and geopotential height (first row), sea level pressure (second row) during years with the positive phase of NAO. Composite of seasonal anoma- lies in $850 \mathrm{mb}$ winds and geopotential height (third row), sea level pressure (fourth row) during years with the negative phase of NAO
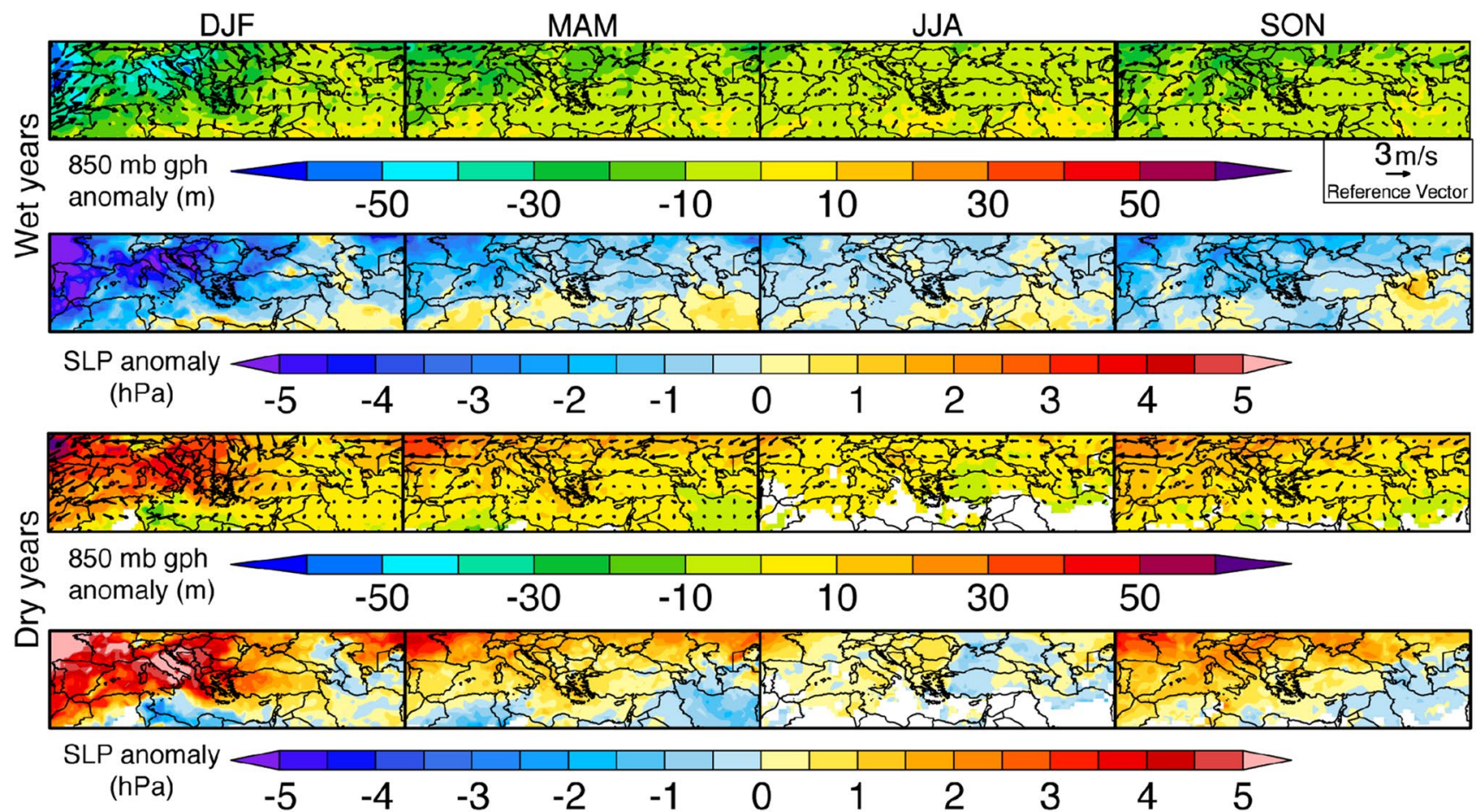

Fig. 17 Composite of seasonal anomalies in $850 \mathrm{mb}$ winds and geopotential height (first row), sea level pressure (second row) during wet years. Composite of seasonal anomalies in $850 \mathrm{mb}$ winds and geo- potential height (third row), sea level pressure (fourth row) during dry years. Wet and dry years at each grid point are based on the \pm 1 standard deviation threshold 


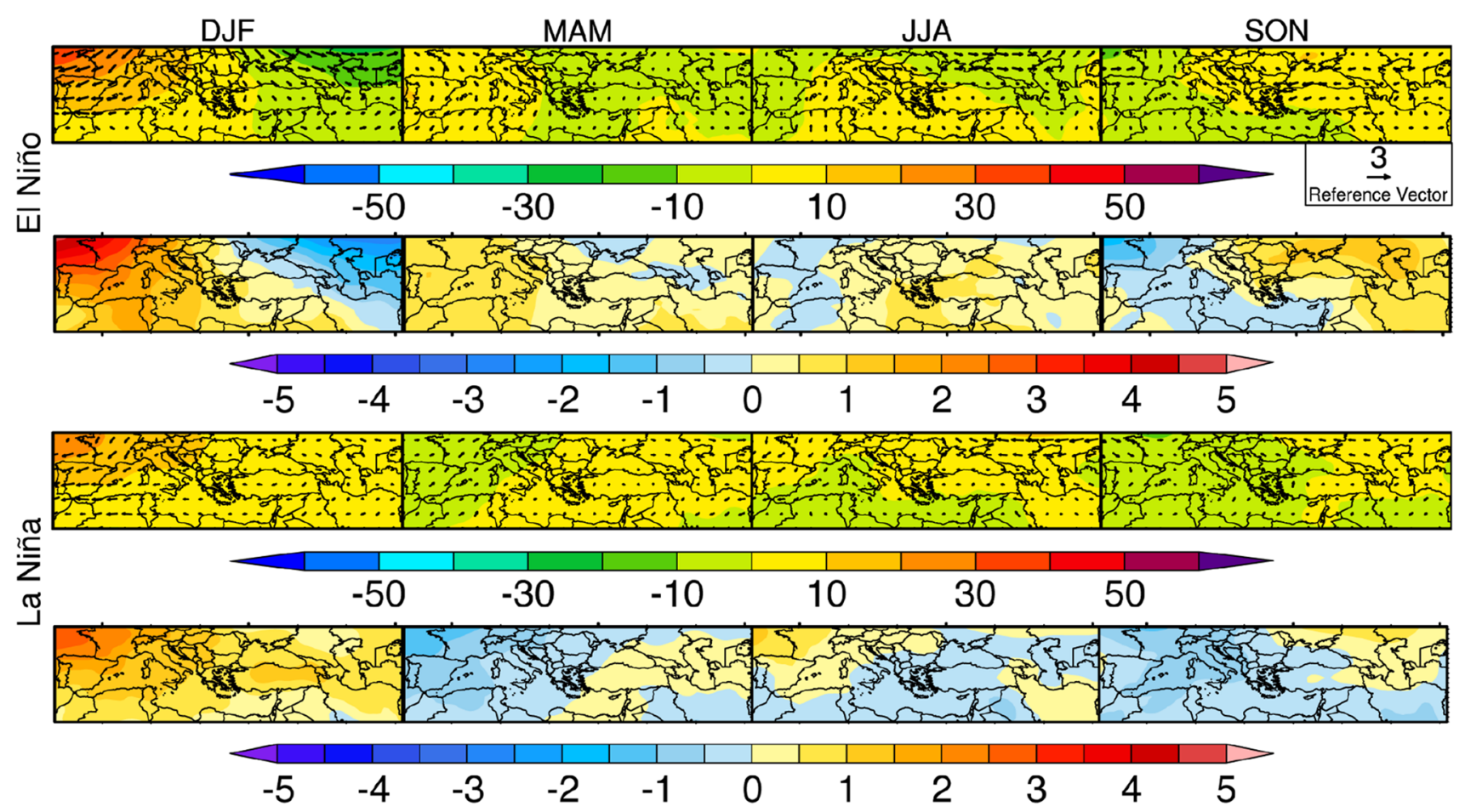

Fig. 18 Composite of seasonal anomalies in $850 \mathrm{mb}$ winds and geopotential height (first row), sea level pressure (second row) during the El Niño. Composite of seasonal anomalies in $850 \mathrm{mb}$ winds and geo-

Acknowledgements We thank two anonymous reviewers for their helpful feedback. This study was funded by the Regional and Global Climate Modeling Program within the Office of Science of the US Department of Energy (DOE), research Grant 116Y136 by the Scientific and Technological Research Council of Turkey (TUBITAK), and research Grant 40248 by the Scientific Research Projects Coordination Unit of Istanbul Technical University (ITU). MA was supported by the National Climate-Computing Research Center which is located within the National Center for Computational Sciences at the Oak Ridge National Laboratory (ORNL) and supported under a Strategic Partnership Project, 2316-T849-08, between DOE and NOAA. UT was supported by the National Center for Atmospheric Research, which is a major facility sponsored by the National Science Foundation under Cooperative Agreement no. 1852977. Support for data analysis is provided by the Oak Ridge Leadership Computing Facility at the ORNL. This manuscript has been co-authored by employees of Oak Ridge National Laboratory, managed by UT Battelle, LLC, under contract DE-AC05-00OR22725 with the U.S. Department of Energy. The publisher, by accepting the article for publication, acknowledges that the United States Government retains a non-exclusive, paid-up, irrevocable, world-wide license to publish or reproduce the published form of this manuscript, or allow others to do so, for United States Government purposes. The Department of Energy will provide public access to these results of federally sponsored research in accordance with the DOE Public Access Plan (https://energy.gov/downloads/doepublic-access-plan).

Open Access This article is licensed under a Creative Commons Attribution 4.0 International License, which permits use, sharing, adaptation, distribution and reproduction in any medium or format, as long as you give appropriate credit to the original author(s) and the source, provide a link to the Creative Commons licence, and indicate if changes potential height (third row), sea level pressure (fourth row) during the La Niña years

were made. The images or other third party material in this article are included in the article's Creative Commons licence, unless indicated otherwise in a credit line to the material. If material is not included in the article's Creative Commons licence and your intended use is not permitted by statutory regulation or exceeds the permitted use, you will need to obtain permission directly from the copyright holder. To view a copy of this licence, visit http://creativecommons.org/licenses/by/4.0/.

\section{References}

Alpert P, Baldi M, Ilani R, Krichak S, Price C, Rodó X, Saaroni H, Ziv B, Kishcha P, Barkan J, Mariotti A, Xoplaki E (2006) Chapter 2 Relations between climate variability in the Mediterranean region and the tropics: ENSO, South Asian and African monsoons, hurricanes and Saharan dust. Developments in earth and environmental sciences. Elsevier, New York, pp 149-177. https://doi.org/10.1016/S1571-9197(06)80005-4

Ashfaq M, Rastogi D, Mei R, Touma D, Ruby Leung L (2017) Sources of errors in the simulation of south Asian summer monsoon in the CMIP5 GCMs. Clim Dyn 49:193-223. https:// doi.org/10.1007/s00382-016-3337-7

Awan NK, Formayer H (2017) Cutoff low systems and their relevance to large-scale extreme precipitation in the European Alps. Theor Appl Climatol 129:149-158. https://doi.org/10.1007/ s00704-016-1767-0

Beck HE, Wood EF, Pan M, Fisher CK, Miralles DG, van Dijk AIJM, McVicar TR, Adler RF (2019) MSWEP V2 global 3-hourly $0.1^{\circ}$ precipitation: methodology and quantitative assessment. Bull Am Meteorol Soc 100:473-500. https://doi.org/10.1175/ BAMS-D-17-0138.1 
Bozkurt D, Ezber Y, Sen OL (2019) Role of the East Asian trough on the eastern Mediterranean temperature variability in early spring and the extreme case of 2004 warm spell. Clim Dyn 53:2309-2326. https://doi.org/10.1007/s00382-019-04847-5

Brönnimann S (2007) Impact of El Niño-Southern Oscillation on European climate: ENSO impact on EUROPE. Rev Geophys. https://doi.org/10.1029/2006RG000199

Brönnimann S, Xoplaki E, Casty C, Pauling A, Luterbacher J (2006) ENSO influence on Europe during the last centuries. Clim Dyn 28:181-197. https://doi.org/10.1007/s00382-006-0175-z

Brubaker KL, Entekhabi D, Eagleson PS (1993) Estimation of continental precipitation recycling. J Clim 6:1077-1089. https ://doi.org/10.1175/1520-0442(1993)006\%3c1077:EOCPR $\% 3 \mathrm{e} 2.0 . \mathrm{CO} ; 2$

Burde GI, Zangvil A (2001) The estimation of regional precipitation recycling. Part I: review of recycling models. J Clim 14:24972508. https://doi.org/10.1175/1520-0442(2001)014\%3c249 7:TEORPR\%3e2.0.CO;2

Christensen J, Hewitson B, Busuioc A, Chen A, Gao X, Held I, Jones R, Kolli RK, Kwon WT, Laprise R, Mearns L, Menéndez C, Räisänen J, Rinke A, Sarr A, Whetton P (2007) Regional climate projections

Ciric D, Nieto R, Losada L, Drumond A, Gimeno L (2018) The mediterranean moisture contribution to climatological and extreme monthly continental precipitation. Water 10:519. https ://doi.org/10.3390/w10040519

Dee DP, Uppala SM, Simmons AJ, Berrisford P, Poli P, Kobayashi S, Andrae U, Balmaseda MA, Balsamo G, Bauer P, Bechtold P, Beljaars ACM, van de Berg L, Bidlot J, Bormann N, Delsol C, Dragani R, Fuentes M, Geer AJ, Haimberger L, Healy SB, Hersbach H, Hólm EV, Isaksen L, Kållberg P, Köhler M, Matricardi M, McNally AP, Monge-Sanz BM, Morcrette J-J, Park B-K, Peubey C, de Rosnay P, Tavolato C, Thépaut J-N, Vitart F (2011) The ERA-interim reanalysis: configuration and performance of the data assimilation system. Q J R Meteorol Soc 137:553-597. https://doi.org/10.1002/qj.828

Dezfuli A (2019) Rare atmospheric river caused record floods across the Middle East. Am Meteorol Soc Bull. https://doi. org/10.1175/BAMS-D-19-0247.1

Dominguez F, Kumar P (2008) Precipitation recycling variability and ecoclimatological stability - a study using NARR data. Part I: Central U. S. Plains Ecoregion. J Clim 21:5165-5186. https:// doi.org/10.1175/2008JCLI1756.1

Dominguez F, Kumar P, Liang X-Z, Ting M (2006) Impact of atmospheric moisture storage on precipitation recycling. J Clim 19:1513-1530. https://doi.org/10.1175/JCLI3691.1

Drumond A, Nieto R, Hernandez E, Gimeno L (2011) A Lagrangian analysis of the variation in moisture sources related to drier and wetter conditions in regions around the Mediterranean Basin. Nat Hazards Earth Syst Sci 11:2307-2320. https://doi. org/10.5194/nhess-11-2307-2011

Dünkeloh A, Jacobeit J (2003) Circulation dynamics of Mediterranean precipitation variability 1948-98: circulation dynamics of mediterranean precipitation variability. Int J Climatol 23:1843-1866. https://doi.org/10.1002/joc.973

Ebita A, Kobayashi S, Ota Y, Moriya M, Kumabe R, Onogi K, Harada Y, Yasui S, Miyaoka K, Takahashi K, Kamahori H, Kobayashi C, Endo H, Soma M, Oikawa Y, Ishimizu T (2011) The Japanese 55-year reanalysis "JRA-55": an interim report. SOLA 7:149-152. https://doi.org/10.2151/sola.2011-038

Eltahir EAB, Bras RL (1996) Precipitation recycling. Rev Geophys 34:367-378. https://doi.org/10.1029/96RG01927

Funk C, Peterson P, Landsfeld M, Pedreros D, Verdin J, Shukla S, Husak G, Rowland J, Harrison L, Hoell A, Michaelsen J (2015) The climate hazards infrared precipitation with stations-a new environmental record for monitoring extremes. Sci Data. https ://doi.org/10.1038/sdata.2015.66

Gimeno L, Stohl A, Trigo RM, Dominguez F, Yoshimura K, Yu L, Drumond A, Durán-Quesada AM, Nieto R (2012) Oceanic and terrestrial sources of continental precipitation. Rev Geophys. https://doi.org/10.1029/2012RG000389

Gómez-Hernández M, Drumond A, Gimeno L, Garcia-Herrera R (2013) Variability of moisture sources in the Mediterranean region during the period 1980-2000: variability of Mediterranean moisture sources. Water Resour Res 49:6781-6794. https ://doi.org/10.1002/wrcr.20538

Hurrell JW (1995) Decadal trends in the North Atlantic oscillation: regional temperatures and precipitation. Science 269:676-679. https://doi.org/10.1126/science.269.5224.676

Insua-Costa D, Miguez-Macho G, Llasat MC (2019) Local and remote moisture sources for extreme precipitation: a study of the two catastrophic 1982 western Mediterranean episodes. Hydrol Earth Syst Sci 23:3885-3900. https://doi.org/10.5194/ hess-23-3885-2019

Kadıoğlu M, Tulunay Y, Borhan Y (1999) Variability of Turkish precipitation compared to El Niño events. Geophys Res Lett 26:1597-1600. https://doi.org/10.1029/1999GL900305

Kelley C, Ting M, Seager R, Kushnir Y (2012) The relative contributions of radiative forcing and internal climate variability to the late 20th Century winter drying of the Mediterranean region. Clim Dyn 38:2001-2015. https://doi.org/10.1007/s00382-011-1221-z

Maheras P, Xoplaki E, Kutiel H (1999) Wet and dry monthly anomalies across the Mediterranean Basin and their relationship with circulation, 1860-1990. Theor Appl Climatol 64:189-199. https://doi. org/10.1007/s007040050122

Mariotti A (2002) Euro-Mediterranean rainfall and ENSO-a seasonally varying relationship. Geophys Res Lett. https://doi. org/10.1029/2001GL014248

Mariotti A (2007) How ENSO impacts precipitation in southwest central Asia: ENSO impact on southwest Central Asia. Geophys Res Lett. https://doi.org/10.1029/2007GL030078

Mariotti A, Struglia MV, Zeng N, Lau K-M (2002) The hydrological cycle in the Mediterranean region and implications for the water budget of the Mediterranean sea. J Clim 15:1674-1690. https://doi.org/10.1175/1520-0442(2002)015\%3c1674:THCIT $\mathrm{M} \% 3 \mathrm{e} 2.0 . \mathrm{CO} ; 2$

Martens B, Miralles DG, Lievens H, van der Schalie R, de Jeu RAM, Fernández-Prieto D, Beck HE, Dorigo WA, Verhoest NEC (2017) GLEAM v3: satellite-based land evaporation and rootzone soil moisture. Geosci Model Dev 10:1903-1925. https://doi. org/10.5194/gmd-10-1903-2017

Martinez JA, Dominguez F (2014) Sources of atmospheric moisture for the La Plata River Basin*. J Clim 27:6737-6753. https://doi. org/10.1175/JCLI-D-14-00022.1

Mei R, Ashfaq M, Rastogi D, Leung LR, Dominguez F (2015) Dominating controls for Wetter South Asian Summer monsoon in the twenty-first century. J Clim 28:3400-3419. https://doi. org/10.1175/JCLI-D-14-00355.1

New M, Lister D, Hulme M, Makin I (2002) A high-resolution data set of surface climate over global land areas. Clim Res 21:1-25. https ://doi.org/10.3354/cr021001

Nieto R, Gimeno L (2019) A database of optimal integration times for Lagrangian studies of atmospheric moisture sources and sinks. Sci Data. https://doi.org/10.1038/s41597-019-0068-8

Nieto R, Gimeno L, Drumond A, Hernandez E (2010) A Lagrangian identification of the main moisture sources and sinks affecting the Mediterranean area. WSEAS Trans Environ 6:10

Önol B, Bozkurt D, Turuncoglu UU, Sen OL, Dalfes HN (2014) Evaluation of the twenty-first century RCM simulations driven by multiple GCMs over the Eastern Mediterranean-Black Sea region. Clim Dyn 42:1949-1965. https://doi.org/10.1007/s00382-013-1966-7 
Pathak A, Ghosh S, Martinez JA, Dominguez F, Kumar P (2017) Role of oceanic and land moisture sources and transport in the seasonal and interannual variability of Summer Monsoon in India. J Clim 30:1839-1859. https://doi.org/10.1175/JCLI-D-16-0156.1

Price C, Stone L, Huppert A, Rajagopalan B, Alpert P (1998) A possible link between El Niño and precipitation in Israel. Geophys Res Lett 25:3963-3966. https://doi.org/10.1029/1998GL900098

Rienecker MM, Suarez MJ, Gelaro R, Todling R, Bacmeister J, Liu E, Bosilovich MG, Schubert SD, Takacs L, Kim G-K, Bloom S, Chen J, Collins D, Conaty A, da Silva A, Gu W, Joiner J, Koster RD, Lucchesi R, Molod A, Owens T, Pawson S, Pegion P, Redder CR, Reichle R, Robertson FR, Ruddick AG, Sienkiewicz M, Woollen J (2011) MERRA: NASA's modern-era retrospective analysis for research and applications. J Clim 24:3624-3648. https ://doi.org/10.1175/JCLI-D-11-00015.1

Roxy MK, Ghosh S, Pathak A, Athulya R, Mujumdar M, Murtugudde R, Terray P, Rajeevan M (2017) A threefold rise in widespread extreme rain events over central India. Nat Commun. https://doi. org/10.1038/s41467-017-00744-9

Saha S, Moorthi S, Pan H-L, Wu X, Wang J, Nadiga S, Tripp P, Kistler R, Woollen J, Behringer D, Liu H, Stokes D, Grumbine R, Gayno G, Wang J, Hou Y-T, Chuang H, Juang H-MH, Sela J, Iredell M, Treadon R, Kleist D, Van Delst P, Keyser D, Derber J, Ek M, Meng J, Wei H, Yang R, Lord S, van den Dool H, Kumar A, Wang W, Long C, Chelliah M, Xue Y, Huang B, Schemm J-K, Ebisuzaki W, Lin R, Xie P, Chen M, Zhou S, Higgins W, Zou C-Z, Liu Q, Chen Y, Han Y, Cucurull L, Reynolds RW, Rutledge G, Goldberg M (2010) The NCEP climate forecast system reanalysis. Bull Am Meteorol Soc 91:1015-1058. https://doi.org/10.1175/2010B AMS3001.1

Saha S, Moorthi S, Wu X, Wang J, Nadiga S, Tripp P, Behringer D, Hou Y-T, Chuang H, Iredell M, Ek M, Meng J, Yang R, Mendez MP, van den Dool H, Zhang Q, Wang W, Chen M, Becker E (2014) The NCEP climate forecast system version 2. J Clim 27:2185-2208. https://doi.org/10.1175/JCLI-D-12-00823.1

Sahana AS, Pathak A, Roxy MK, Ghosh S (2019) Understanding the role of moisture transport on the dry bias in Indian monsoon simulations by CFSv2. Clim Dyn 52:637-651. https://doi.org/10.1007/ s00382-018-4154-y

Sandeep S, Ajayamohan RS (2018) Modulation of winter precipitation dynamics over the Arabian Gulf by ENSO. J Geophys Res Atmos 123:198-210. https://doi.org/10.1002/2017JD027263

Schicker I, Radanovics S, Seibert P (2010a) Origin and transport of Mediterranean moisture and air. Atmos Chem Phys 20:17

Sen OL, Ezber Y, Bozkurt D (2018) Euro-Mediterranean climate variability in boreal winter: a potential role of the East Asian trough. Dyn Clim. https://doi.org/10.1007/s00382-018-4573-9

Shaman J, Tziperman E (2011) An atmospheric teleconnection linking ENSO and Southwestern European precipitation. J Clim 24:124139. https://doi.org/10.1175/2010JCLI3590.1
Stohl A, James P (2004) A Lagrangian analysis of the atmospheric branch of the global water cycle. Part I: method description, validation, and demonstration for the August 2002 flooding in Central Europe. J Hydrometeorol 5:656-678. https ://doi.org/10.1175/1525-7541(2004)005\%3c0656:ALAOT $\mathrm{A} \% 3 \mathrm{e} 2.0 . \mathrm{CO} ; 2$

Stohl A, James P (2005) A Lagrangian analysis of the atmospheric branch of the global water cycle. Part II: moisture transports between earth's ocean basins and river catchments. J Hydrometeorol 6:961-984. https://doi.org/10.1175/JHM470.1

Trenberth KE (1999) Atmospheric moisture recycling: role of advection and local evaporation. J Clim 12:1368-1381. https ://doi.org/10.1175/1520-0442(1999)012\%3c1368:AMRRO $\mathrm{A} \% 3 \mathrm{e} 2.0 . \mathrm{CO} ; 2$

Turuncoglu UU, Sannino G (2017) Validation of newly designed regional earth system model (RegESM) for Mediterranean Basin. Clim Dyn 48:2919-2947. https://doi.org/10.1007/s0038 2-016-3241-1

Volosciuk C, Maraun D, Semenov VA, Tilinina N, Gulev SK, Latif M (2016) Rising Mediterranean sea surface temperatures amplify extreme summer precipitation in Central Europe. Sci Rep. https ://doi.org/10.1038/srep32450

Wanner H, Rickli R, Salvisberg E, Schmutz C, Schepp M (1997) Global climate change and variability and its influence on Alpine climate ? Concepts and observations. Theor Appl Climatol 58:221-243. https://doi.org/10.1007/BF00865022

Xoplaki E, González-Rouco JF, Luterbacher J, Wanner H (2004) Wet season Mediterranean precipitation variability: influence of large-scale dynamics and trends. Clim Dyn 23:63-78. https://doi. org/10.1007/s00382-004-0422-0

Xoplaki E, Trigo RM, García-Herrera R, Barriopedro D, D’Andrea F, Fischer EM, Gimeno L, Gouveia C, Hernández E, Kuglitsch FG, Mariotti A, Nieto R, Pinto JG, Pozo-Vázquez D, Saaroni H, Toreti A, Trigo IF, Vicente-Serrano SM, Yiou P, Ziv B (2012) Largescale atmospheric circulation driving extreme climate events in the Mediterranean and its related impacts. The climate of the Mediterranean region. Elsevier, New Yorkpp, pp 347-417. https ://doi.org/10.1016/B978-0-12-416042-2.00006-9

Zanchettin D, Franks SW, Traverso P, Tomasino M (2008) On ENSO impacts on European wintertime rainfalls and their modulation by the NAO and the Pacific multi-decadal variability described through the PDO index. Int J Climatol 28:995-1006. https://doi. org/10.1002/joc. 1601

Publisher's Note Springer Nature remains neutral with regard to jurisdictional claims in published maps and institutional affiliations. 